TECTONICS, VOL. 12, NO. 2, PAGES 387-409, APRIL 1993

\section{GENESIS AND EVOLUTION OF A PERMIAN-JURASSIC MAGMATIC ARC/ACCRETIONARY WEDGE, AND REEVALUATION OF TERRANES IN THE CENTRAL KLAMATH MOUNTAINS}

Bradley R. Hacker, W. G. Ernst, and Michael O. McWilliams Department of Geology, School of Earth Sciences, Stanford University, Stanford, Califomia

\begin{abstract}
Investigation of key areas of the central Klamath Mountains demonstrates that genetic relationships connect several regionally significant lithologic units that were previously considered to be separate tectonostratigraphic terranes. The rocks embody an intraoceanic tholeiitic to alkaline magmatic arc and contiguous accretionary wedge formed in Permian to Middle Jurassic time. The Eastern Hayfork and St Claire Creek units comprise Permian-Jurassic oceanic sedimentary rocks deposited nearby and coeval with eruption of the North Fork-Salmon River volcanoplutonic arc. The more inboard St Claire Creek unit consists of stratigraphically coherent chert and minor argillite probably deposited in a back-arc setting, whereas the more outboard Eastern Hayfork sedimentary rocks were disrupted during formation of an accretionary wedge. The volcanoplutonic North Fork-Salmon River arc extends for $200 \mathrm{~km}$ in the central Klamath Mountains and was active episodically or continuously from Permian through Middle Jurassic time. Alkalic members of the mafic igneous suite may have erupted following subduction of a spreading center. A varied heating history has produced an amalgam of submarine and regional low-pressure, moderate-temperature metamorphism, overprinted locally by contact metamorphism. Geochronology of weakly metamorphosed mafic dikes/sills ( 10 new ${ }^{40} \mathrm{Ar} /{ }^{39} \mathrm{Ar}$ analyses) suggests that significant heat was retained regionally into Early Cretaceous time.
\end{abstract}

\section{INTRODUCTION}

As an aid to understanding the geology of the Klamath Mountains, Irwin [1972, p. C103] introduced the term 'terrane' to refer to "an association of geologic features, such as stratigraphic formations, intrusive rocks, mineral deposits, and tectonic history, some or all of which lend a distinguishing characteristic to a particular tract of rocks and which differ from those of an adjacent terrane". Irwin [1972, p. C109] also noted that "The apparent juxtaposition of the terranes is most readily explained by considering them to have been widely separated when formed and subsequently to have been telescoped together along"..."thrust faults." Since then, terrane nomenclature has been applied worldwide. In the extreme, it has been deemed "more reasonable to assume allochthoneity among terranes" [Howell and Jones, 1984, p. 6] and that "minimum nominal displacements [between terranes] of a few hundred kilometers appear to be required, but in fact, most displacements probably were much larger" [Jones, 1991, p. 23].

However, the growing base of petrologic, structural, geochronologic, isotopic, and mapping data has prompted the recognition of magmatic and depositional ties between

Copyright 1993 by the American Geophysical Union.

Paper number 92TC02250.

0278-7407/93/92TC-02250\$10.00
Klamath terranes [e.g., Ando et al., 1977; Burchfiel and Davis, 1981; Wright, 1982; Miller and Saleeby, 1991], in some cases disproving the hypothesis of allochthoneity and the need for large-scale displacement. This paper continues that trend by showing that a key group of Klamath 'terranes' are neither bounded by faults with hundreds to thousands of kilometers of displacement nor demonstrably allochthonous with respect to each other and thus are not terranes sensu stricto. This is significant because the Klamath Mountains orogen, the birthplace of the terrane concept, provides an archetype of continental growth via long-term subduction of oceanic lithosphere. A map of Klamath terranes is shown as Figure 1.

Understanding the processes of orogen construction from oceanic rocks is difficult because of the paucity of coherent stratigraphic sections. The so-called western Paleozoic and Triassic belt has been the most difficult unit in the Klamath Mountains to understand, and yet its large outcrop area and central location- between terranes of the western and eastern Klamaths-make it a linchpin for the entire orogen. This importance of the western Paleozoic and Triassic belt impelled us to synthesize map data for the eastern portion of the belt from its northernmost to southernmost extent (Figure 2). The map depicts one of the largest fossil intraoceanic magmatic arc and accretionary wedge pairs in the world. Along this belt, younger faults expose different levels within the arc, affording an excellent opportunity to study at different structural levels the genesis, deformation, and metamorphism of immature magmatic arcs, accretionary wedges, and ocean basins. This paper integrates our new data with that of previous workers. We have attempted a detailed look at the birth, evolution, and assembly of a major magmatic arc and its associated accretionary complex.

\section{REGIONAL GEOLOGY}

The gross structure of the Klamath Mountains is a structural stack of north-south trending units. Individual units have east dipping bedding and foliation and west vergent folds and are generally separated by west-directed thrust faults. Modeling of gravity [Mortimer, 1985], magnetic [Blakely et al., 1985], and seismic refraction data [Zucca et al., 1986; Fuis et al., 1987] suggests that the thrust sheets dip moderately to depths of $\sim 2-3 \mathrm{~km}$ and then dip gently $\left(-3^{\circ}-9^{\circ}\right)$ eastward for more than $50 \mathrm{~km}$.

Irwin [1966] divided the southern Klamath Mountains into four major belts, the Eastern Klamath, central metamorphic, western Paleozoic and Triassic, and western Jurassic. Later, Irwin [1972] subdivided the largest of these, the westem Paleozoic and Triassic belt, into the Rattlesnake Creek, Hayfork, and North Fork terranes (Figure 3). Hotz [1977] correlated blueschists in the northern Klamaths with the Stuart Fork Formation mapped by Davis and Lipman [1962] in the westem Paleozoic and Triassic belt farther to the south. Mapping by Ando et al. [1977] led them to divide the North Fork into two terranes: (1) a chiefly tholeiitic igneous basement thrust beneath (2) interbedded sedimentary and alkalic volcanic rocks. Blake et al. [1982] renamed the tholeiitic basement the Salmon River terrane and reserved the name North Fork for the sedimentary and alkalic volcanic section. Wright $[1981,1982]$ subdivided the Hayfork into the volcanic Western Hayfork and sedimentary Eastern Hayfork terranes. Since then, effort has focused on extending these terranes into the northern Klamath Mountains. Rawson and Petersen [1982] and Donato et al. [1981] carried the Rattlesnake Creek 


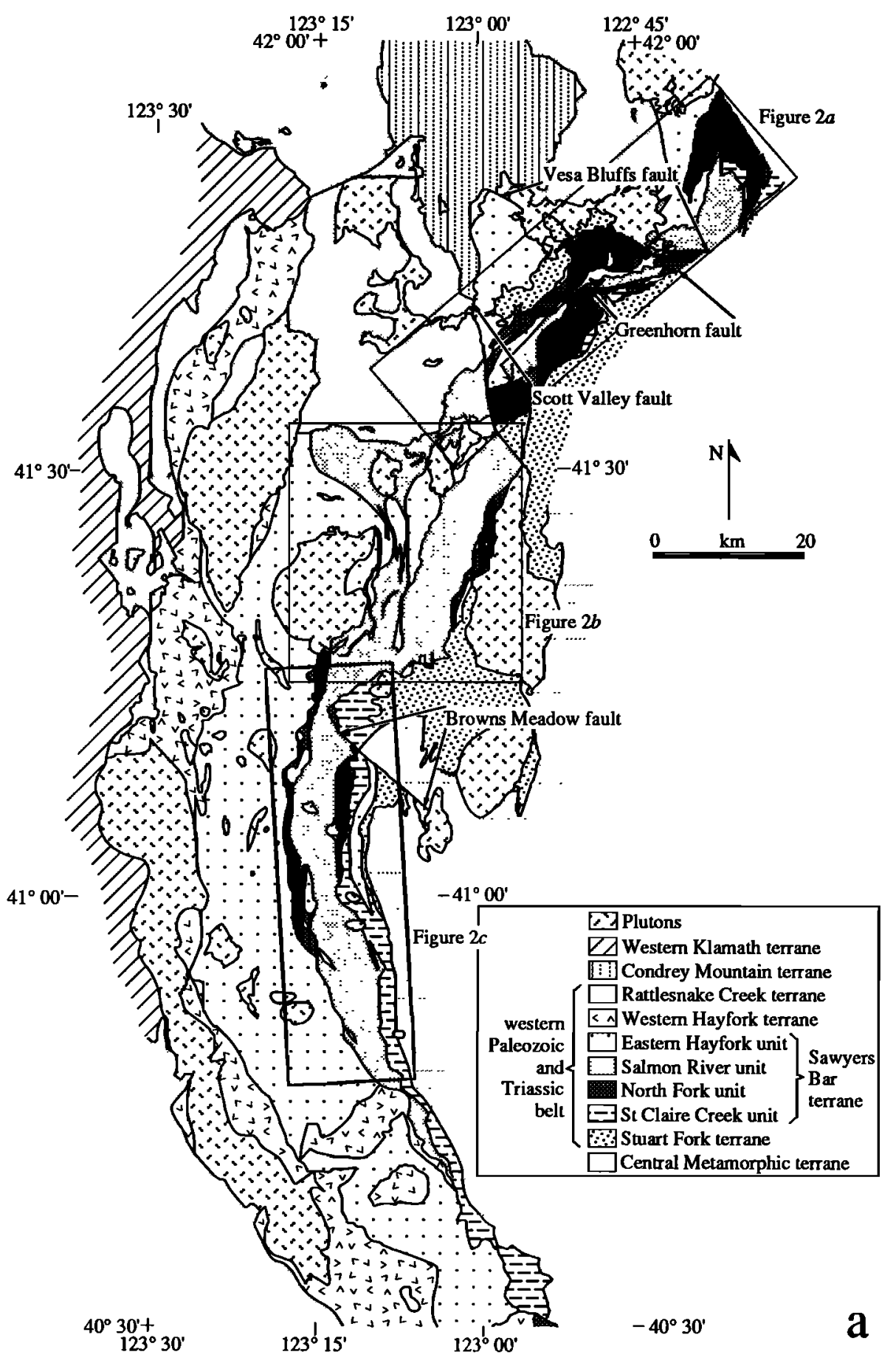

Fig. 1. (a) Terrane map of the central Klamath Mountains in California. The "western Paleozoic and Triassic belt" includes the Rattlesnake Creek, Western Hayfork, Sawyers Bar, and Stuart Fork terranes. Herein, the Yreka-Callahan, Trinity, and Redding terranes are jointly referred to as the "eastern Klamaths." The St Claire Creek unit south of $41^{\circ}$ is mapped in reconnaissance only and should be considered a probable mixture of St Claire Creek and North Fork lithologies. Areas of Figure 2 are shown by rectangles. (b) Sources used to compile the map.

and Hayfork terranes into the northern California Klamaths. Blake et al. [1982] showed the Salmon River terrane reaching the Oregon border, but based on lithological and fossil similarities with the southern Klamath terranes, Mortimer [1984] subdivided Blake et al.'s Salmon River terrane into the
Westem Hayfork, Eastem Hayfork, North Fork, and Salmon River terranes.

Although Mortimer demonstrated that the western Paleozoic and Triassic belt terranes of the southern Klamaths crop out in the northern California Klamaths, the designation of terranes 


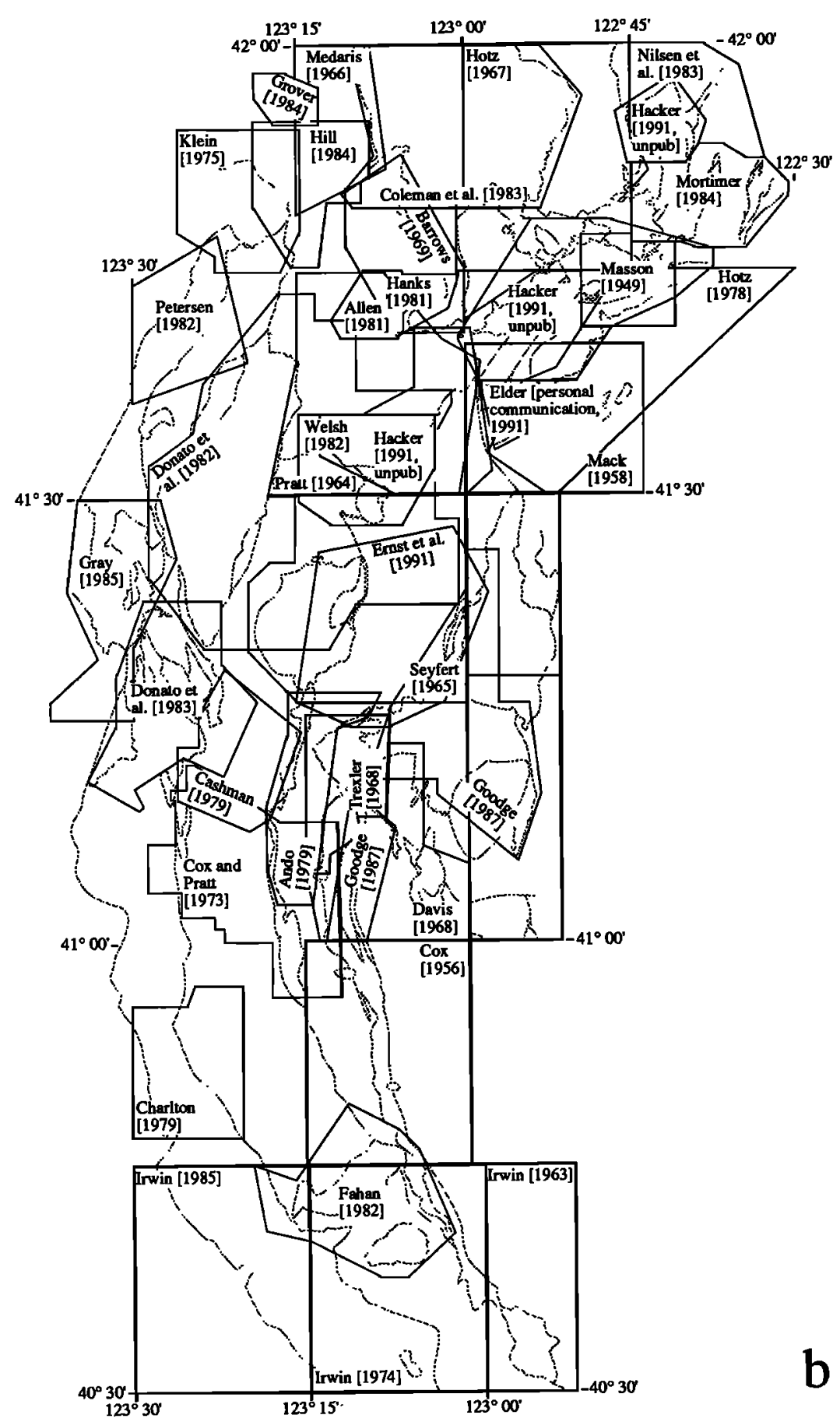

Fig.1 (continued)

in the central Klamaths has remained a subject of considerable disagreement. For instance, it has been suggested that some terranes, such as the North Fork, may not be present in the central Klamaths [Irwin, 1989]. This paper demonstrates that the western Paleozoic and Triassic belt terranes in the northern and southern California Klamaths are contiguous through the central Klamaths. This central area reveals new data for reconstruction of Klamath paleogeography. For example, the Eastern Hayfork, North Fork, and Salmon River units are not wholly fault-bounded entities and are therefore not terranes in the conventional sense. Instead, the units are intimately related to one another by depositional, intrusive, or other types of primary contact and form an important volcanoplutonic arc/accretionary complex described in detail below. The North Fork terrane is also herein subdivided into two units: the sedimentary section is called the St Claire Creek unit, and the alkalic volcanic sequence retains the name North Fork. The purpose of this subdivision is to underscore the differences 


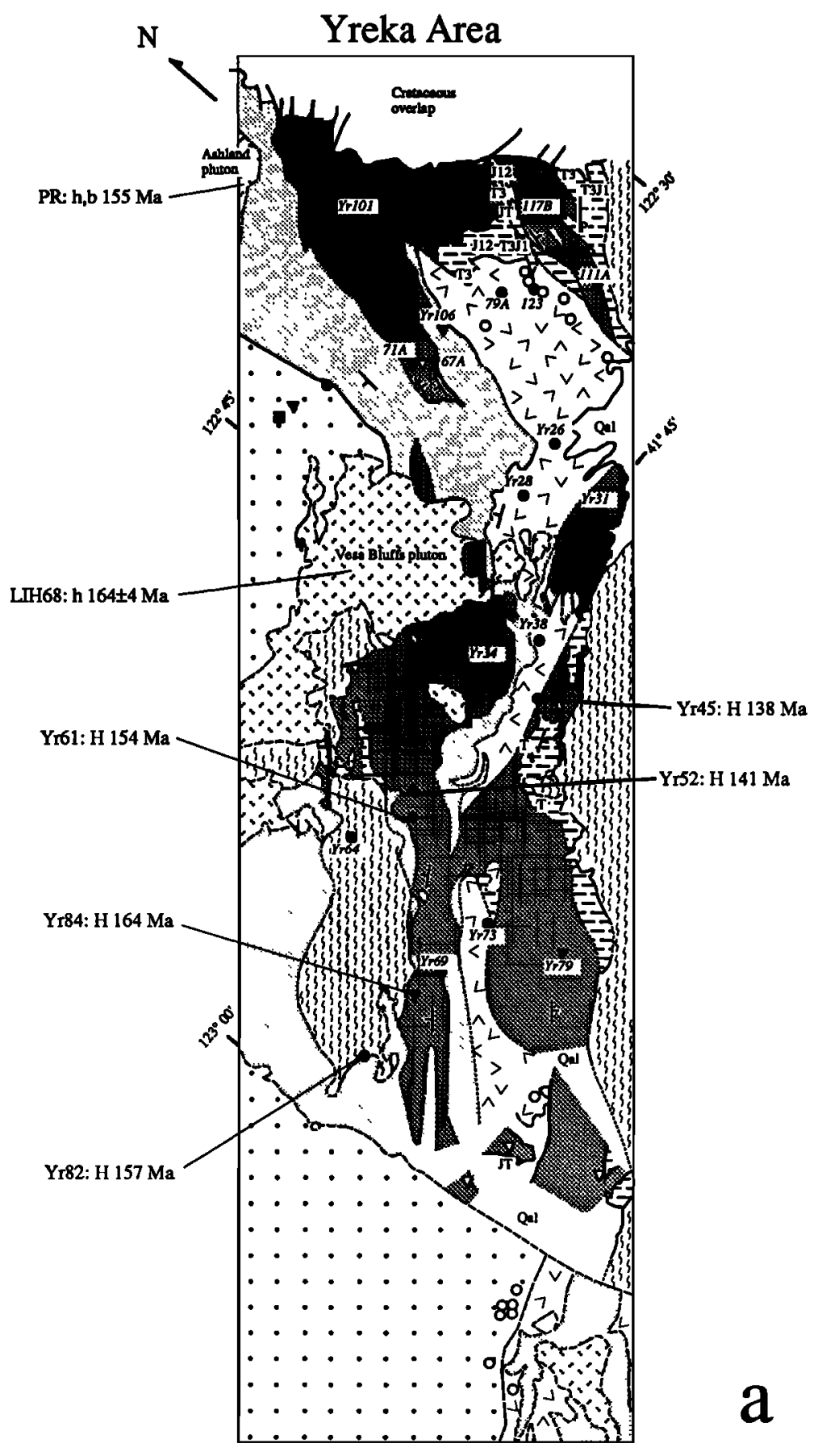

Fig. 2. Map of the North Fork-Salmon River arc and associated tectonostratigraphic units. The southernmost portion of the arc, where late faulting has strongly disrupted primary contacts, has been excluded. Locations of bulk-rock analyses are shown; solid symbols from Emst [1987], Ernst et al. [1991], and this study; open symbols from Ando [1983], Donato [1985], and Hotz [1979]. Radiometric ages are called out. Age prefixes are: K-Ar homblende age, h; K-Ar biotite age, b; Ar/Ar homblende age, $\mathrm{H} ; \mathrm{Pb} / \mathrm{U}$ zircon age, $\mathrm{Z}$; samples dated by Lanphere et al. [1968], LIH68; sample dated by Paul Renne [personal communication, 1991], PR; samples dated by Wright and Fahan [1988], W\&F88; sample age reported by Irwin [1985], I85; and sample dated by Ando et al. [1983], AIJS83; samples with "Yr" prefixes and " $M$ " suffixes dated as part of this study. Radiolarian ages are shown by letters after references cited in text. Unpattemed areas include: Quatemary alluvium, Cretaceous overlapping rocks, and the Rattlesnake Creek, Stuart Fork, and Central Metamorphic terranes. (a) Yreka area; (b) Sawyers Bar area; (c) South Fork Salmon River-North Fork Trinity River area. 


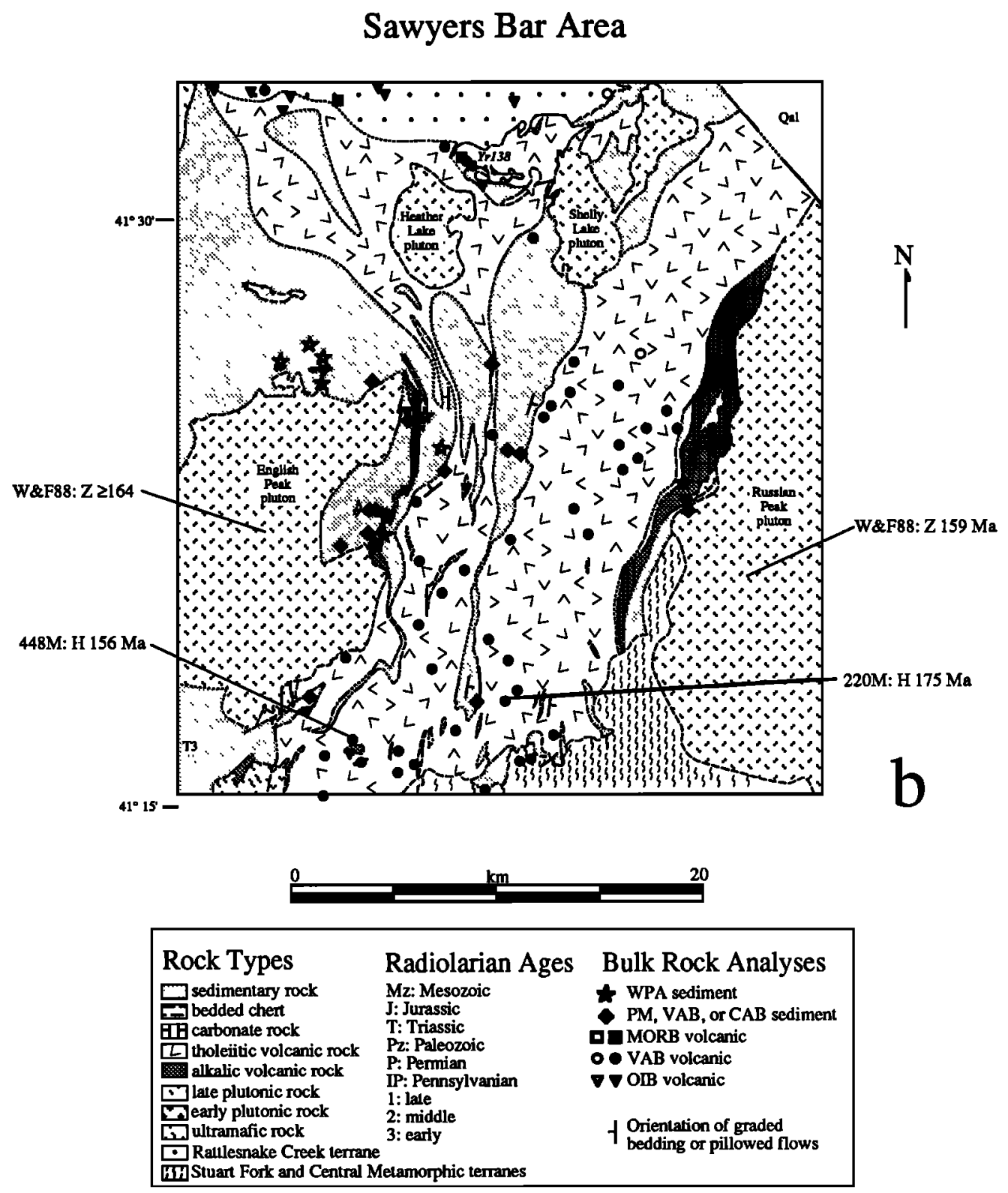

Fig.2 (continued)

between the two sedimentary units, the Eastem Hayfork and St Claire Creek, that are interbedded with the North Fork/Salmon River.

\section{Eastern Hayfork Unit}

The Eastem Hayfork unit varies from a broken formation to melange interpreted to represent an accretionary wedge [Wright, 1981]. The nonexotic (plausibly interbedded) component of the Eastern Hayfork includes rocks grading from radiolarian chert to tuff, pillow lava, and quartzose turbidites [Cashman, 1979; Charlton, 1979; Fahan, 1982; Wright, 1982].

Tuffaceous material and clastic volcanogenic rocks are subordinate to detritus derived from continental or plutonic provenances. Exotic blocks are pebble- to house-sized, and include ultramafic rock, basalt, gabbro, limestone, amphibolite, blueschist, quartzofeldspathic schist, recrystallized chert, and crenulated quartz-mica schist [Cox, 1956; Cashman, 1979; Charlton, 1979; Fahan, 1982; Burton, 1982; Wright, 1982]. The compositions of most mafic blocks are unknown except for one vesicular volcanic boudin that is similar to the North Fork unit (sample Yr106 in Table 1). Cashman [1979] and Wright [1982] suggested that the metamorphic blocks were derived from the more easterly Stuart Fork and Central Metamorphic terranes, and this suggestion has been strengthened by the geochronologic work of Goodge and Renne [1991]. Much of the Eastern Hayfork contains few if any exotic blocks and is instead chiefly disrupted chert, argillite, and mafic volcanogenic rocks.

Limestone blocks in the Eastern Hayfork contain Pennsylvanian, Permian, Early Triassic, Middle Triassic, and Late Triassic fossils, including Late Permian Tethyan 


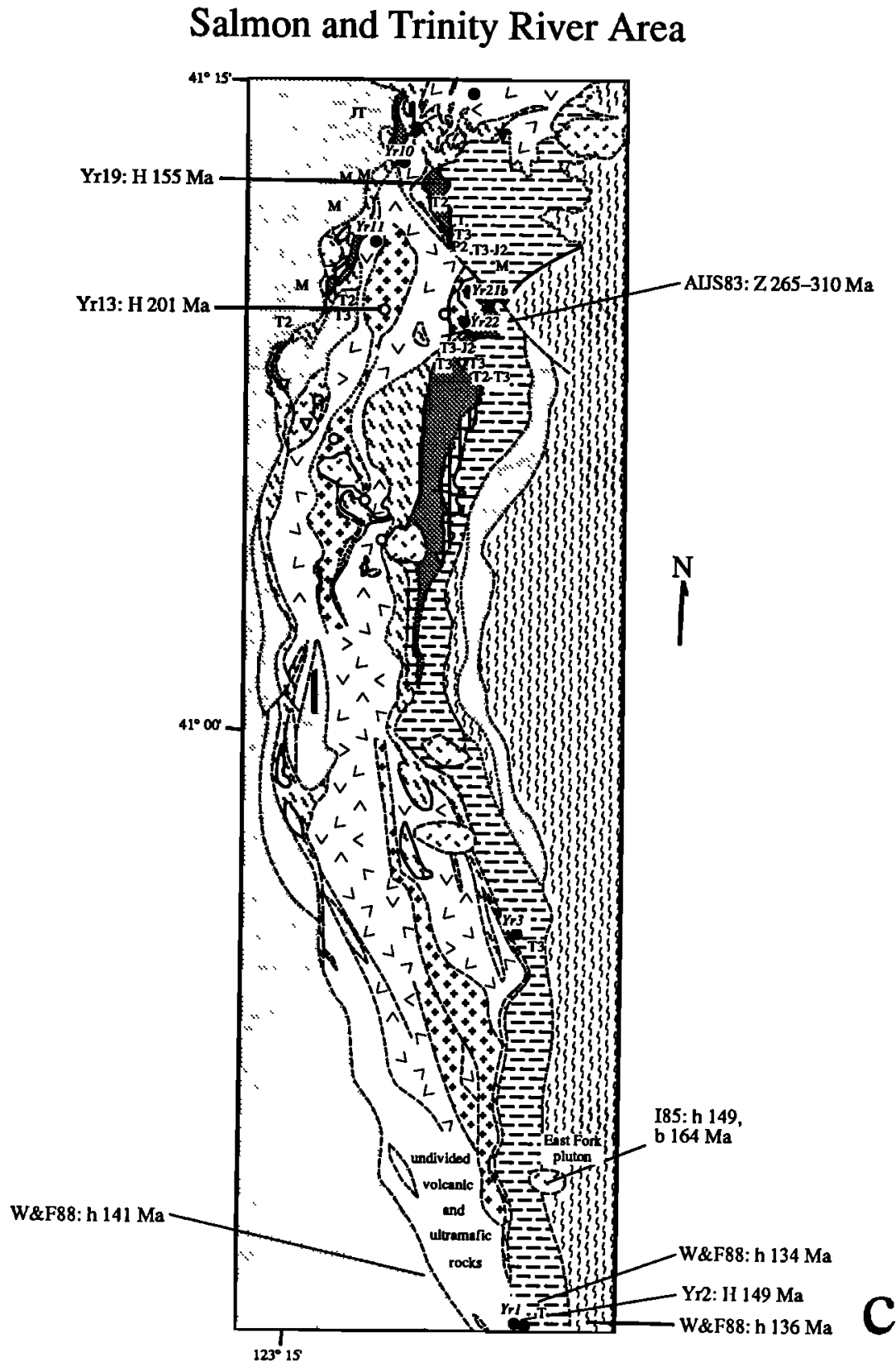

Fig.2 (continued)

fusulinids and coral [Irwin, 1972, 1974; Cox and Pratt, 1973; Irwin et al., 1977, 1983, 1985; Gray, 1986; Miller and Wright, 1987; Stevens et al., 1987, 1991]. Sedimentary structures and fauna in limestone blocks suggest that the limestone was deposited in shallow water [Cox and Pratt, 1973; Cashman, 1979; Fahan, 1982; Wright, 1982]. The discovery of the same Late Permian Tethyan coral in the Eastern Klamath terrane [Stevens et al., 1987] may imply that the limestone blocks are olistoliths derived from eastern paleoPacific seamounts [Miller and Wright, 1987] or the Eastern Klamath. Eastern Hayfork chert contains Late Permian, Middle Triassic, Late Triassic, and Late Triassic to Early Jurassic radiolarians, and Middle Triassic and Late Triassic conodonts [Irwin et al., 1982, 1983, 1985; Ando et al., 1983].
Quartzose blocks contain detrital zircons with $\mathrm{Pb} / \mathrm{Pb}$ ages of 2.0-2.1 Ga, indicating that some debris was ultimately derived from a mature Precambrian continental source [Miller and Saleeby, 1991]. Chemical compositions of Eastem Hayfork sedimentary rocks suggest that material was also derived in part from the adjacent North Fork-Salmon River arc. Floyd et al. [1991] proposed that trace element compositions of fine-grained quartzofeldspathic sedimentary rocks in favorable instances can be used to infer the tectonic environment of the source of the detritus. Many factors such as grain size, sorting, diagenesis, and metamorphism may also affect the composition of sediment, so this approach is open to criticism. Using normalization factors of upper continental crust from Taylor and McLennan [1985] and average values for 


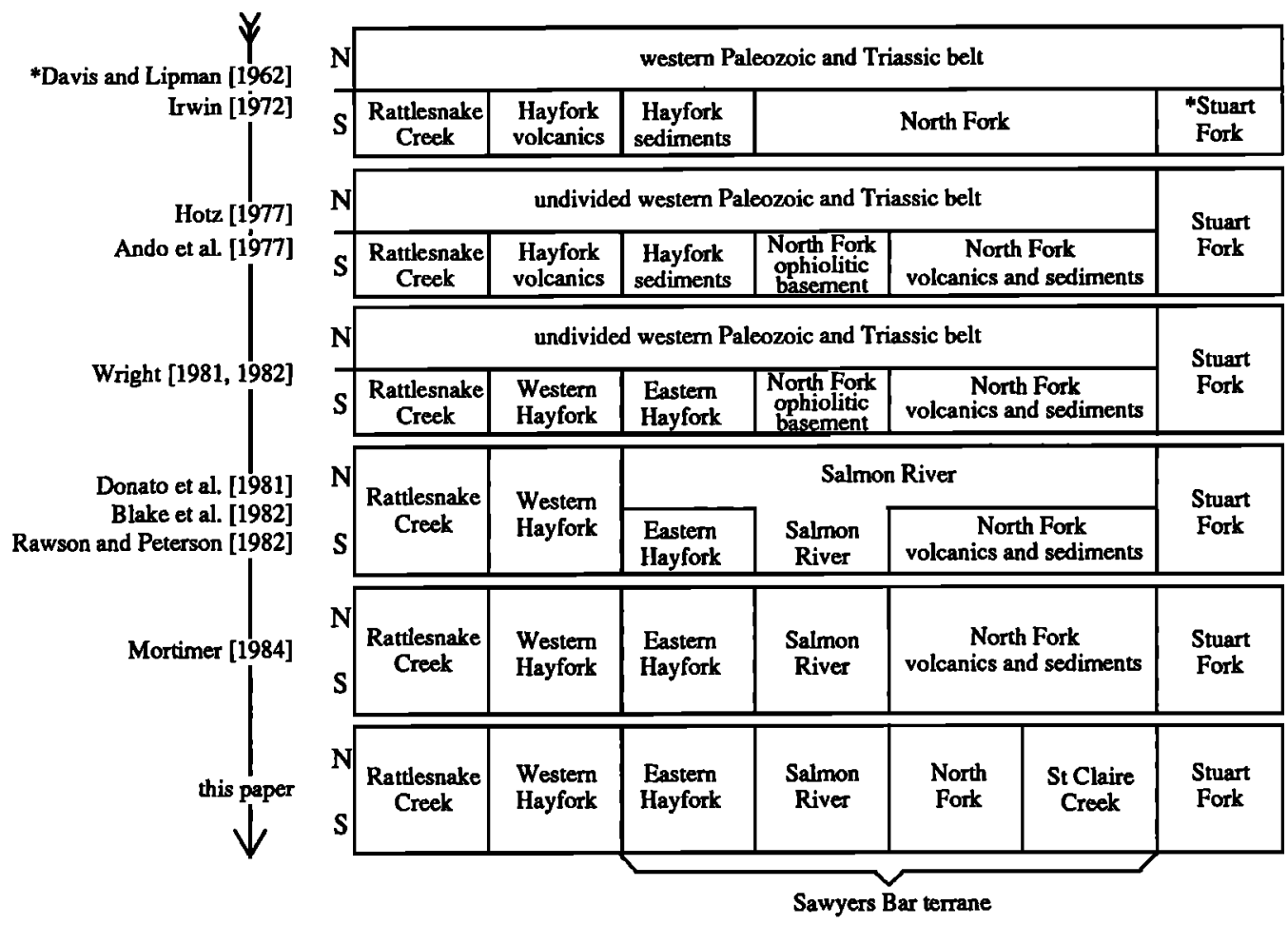

Fig. 3. A history (top to bottom) of the naming and subdivision of terranes in the westem Paleozoic and Triassic belt of the Klamath Mountains. The upper half of each box labeled " $N$ " refers to the northerm California Klamaths, and the lower half "S" refers to the southern Klamath Mountains.

sedimentary rocks derived from oceanic island arcs (VAB), continental arcs or active margins (CAB), oceanic within-plate sources (OIB), and passive margins (PM) compiled by Floyd et al. [1991], about half our analyzed fine-grained quartzofeldspathic sedimentary samples from the Sawyers Bar area (locations shown in Figure 2) have trace element abundances that can be matched to a particular tectonic setting (Figure 4). Eight of our samples appear to have been derived from a within-plate source, and 15 have element abundances appropriate for either VAB, CAB, or PM sources. Although, in principle, it is possible to differentiate among rocks derived from eroding oceanic island arcs, continental arcs, and passive margins, the somewhat disturbed abundance patterns precludes doing so for most of our samples. The highly variable $K, R b$, and $\mathrm{Sr}$ abundances (Figure 4) are probably the result of similar metasomatic addition or leaching [Hacker et al., 1992], and we assume that these elements are no longer present in their original concentrations.

Thus, the Eastern Hayfork comprises broken formation and melange formed prior to Jurassic time. Detritus was derived from a mixture of sources including continental rocks with Precambrian zircons, the eastern Klamaths, alkalic North Fork-like rocks, and a Salmon River-like arc source. Deposition occurred at least from Permian to Late Triassic time (age range of radiolarians). The Eastem Hayfork is inferred to have formed in an accretionary wedge [Wright, 1982], and the fossils in limestone blocks suggest that oceanic lithosphere of Devonian to Late Triassic age may have been subducted beneath it. Alternatively, the Eastem Hayfork may be the result of closure of a fairly small basin that never involved significant subduction, in which case the limestones might be tectonic slivers or olistoliths.

\section{Salmon River Unit}

The Salmon River unit is composed of ultramafic rock, gabbro, diabase, and volcanic rock, which led Irwin [1972] to interpret it as oceanic crust. Others [Blake et al., 1982; Ando et al., 1983; Mortimer, 1984; Saleeby, 1990], have since concurred with this, but Ernst et al. [1991] proposed instead that it is an immature intraoceanic arc.

Ultramafic rock in the Salmon River unit is serpentinized dunite and harzburgite tectonite [Ando, 1979]. The gabbro is chiefly massive with local cumulus layering and contains andesine-bytownite and augite overgrown by igneous pargasite. It grades into massive diabase with similar mineralogy. Overlying massive and locally pillowed volcanic rocks with thin volcaniclastic layers contain clinopyroxene, homblende, and plagioclase, minor spinel, apatite, and possibly anorthoclase; carbonate and chert are present between pillows [Cox, 1956; Ando, 1979; Mortimer, 1984; Ernst et al., 1991].

Salmon River volcanic rocks are similar to immature arc lavas, including having high-field-strength elements depleted below mid-ocean ridge basalts (MORB), and Th levels in excess of MORB (Figure 5; Table 1; Ernst et al. [1991]). Their primitive nature is indicated by $\mathrm{Cr}$ and $\mathrm{Ni}$ contents as high as 1100 and $500 \mathrm{ppm}$, respectively. Flow rocks and dikes show decreasing $\mathrm{Cr}$ and $\mathrm{Ni}$ with decreasing $\mathrm{MgO}$, suggesting fractionation of olivine, homblende, or clinopyroxene. Element-ratio diagrams rule out the participation of olivine and plagioclase but support the contention that clinopyroxene and/or hornblende were fractionating or accumulating phases [Emst et al., 1991]. Decreasing Ti with decreasing $\mathrm{Zr}$ suggests fractionation of a 


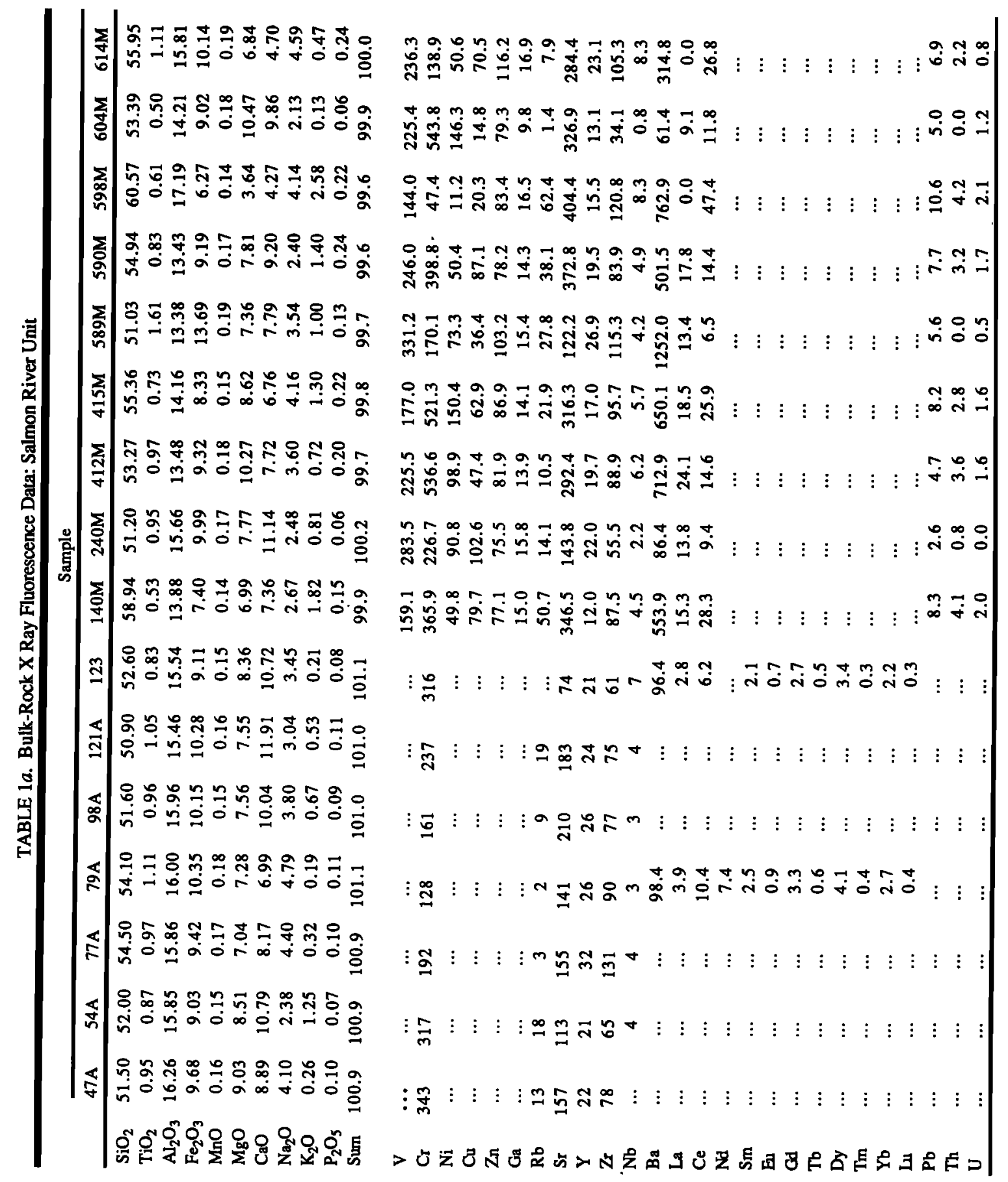




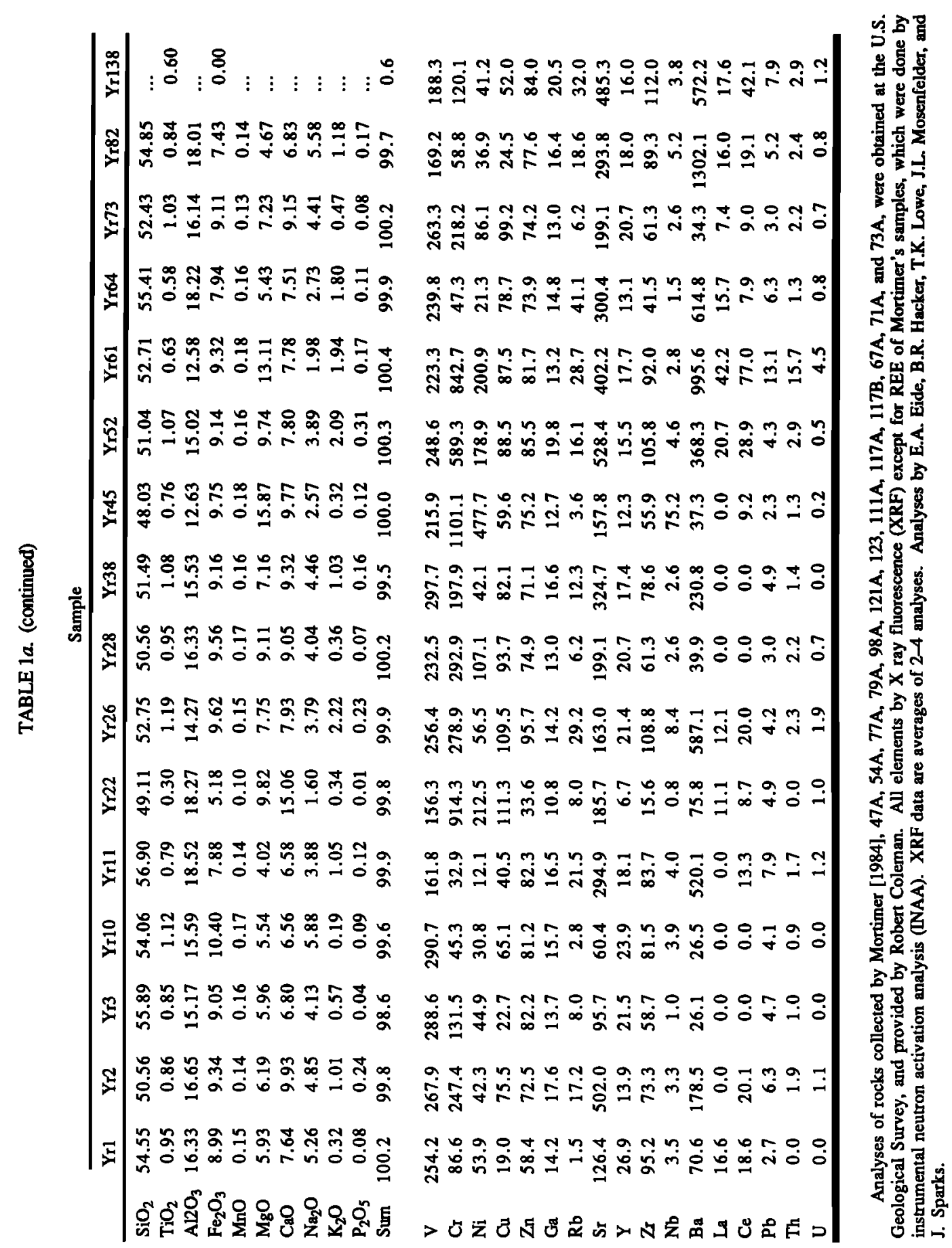




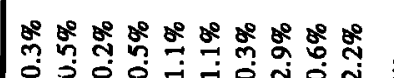

$\vdots \quad \vdots \quad \vdots \quad \vdots \quad \vdots \quad \vdots \quad \vdots \quad \vdots \quad \vdots \quad:$

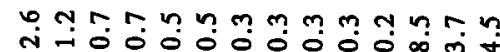

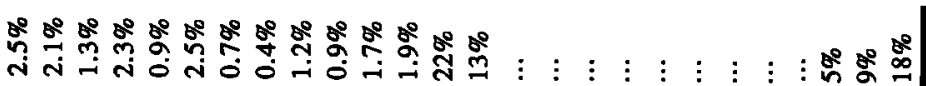

$\stackrel{\infty}{0} \stackrel{\infty}{0}_{0}^{\infty}$

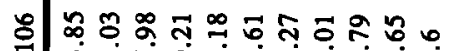

भiं

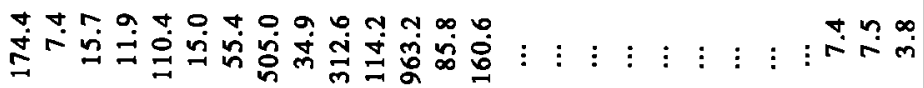

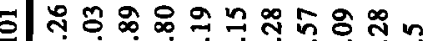

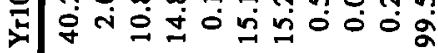

पำ

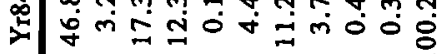

ले

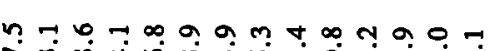

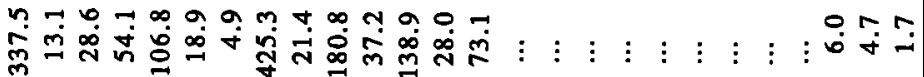

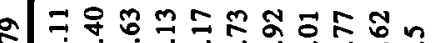

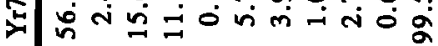

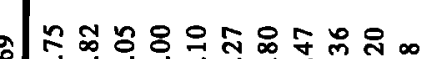

तi

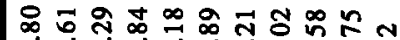

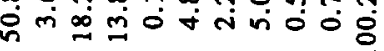

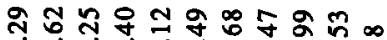

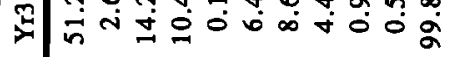

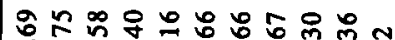

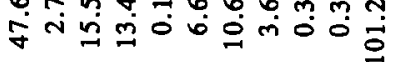

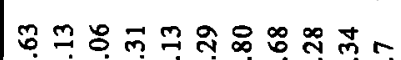

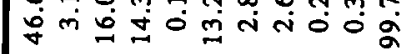

(a)

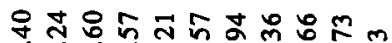

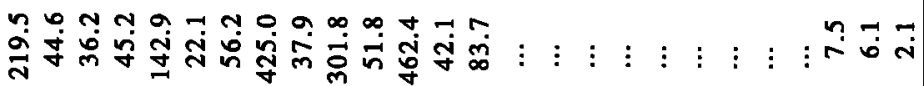

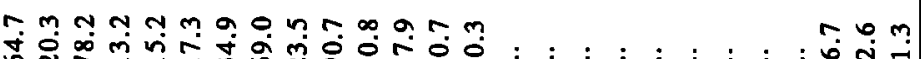

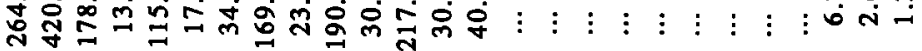

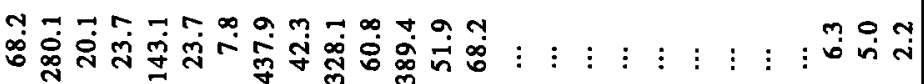

离

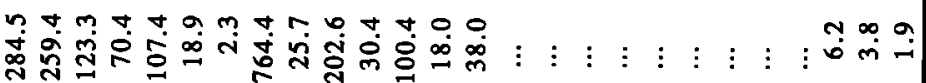

m $\infty a$ t $m \infty$ n no poon

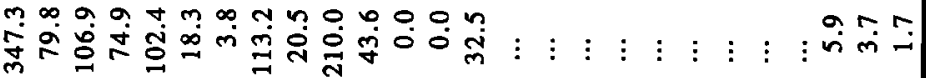

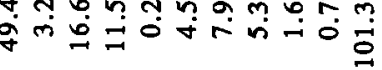

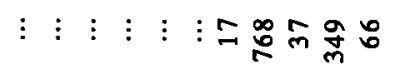

$\$$

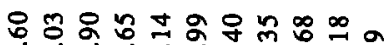

ทें

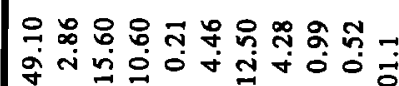

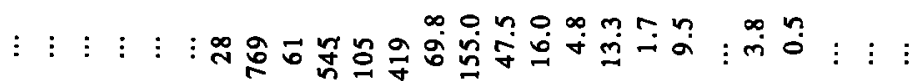

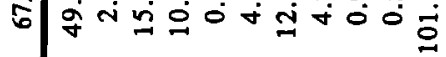

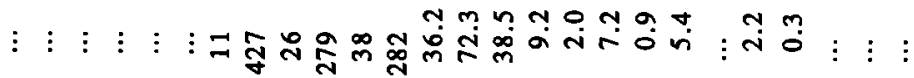

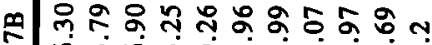

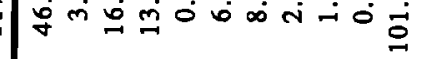

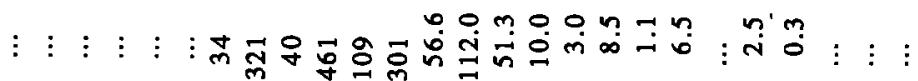

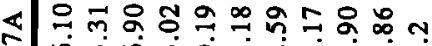

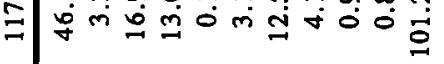

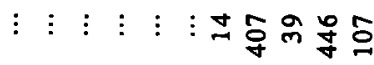

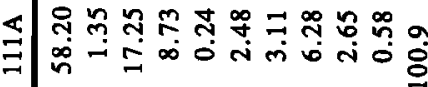

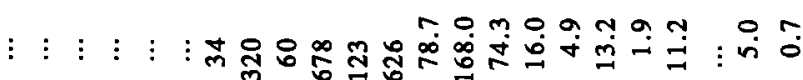

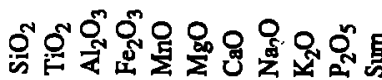

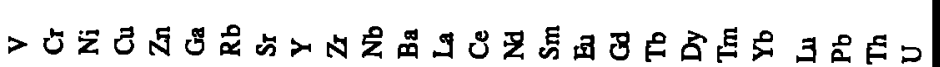



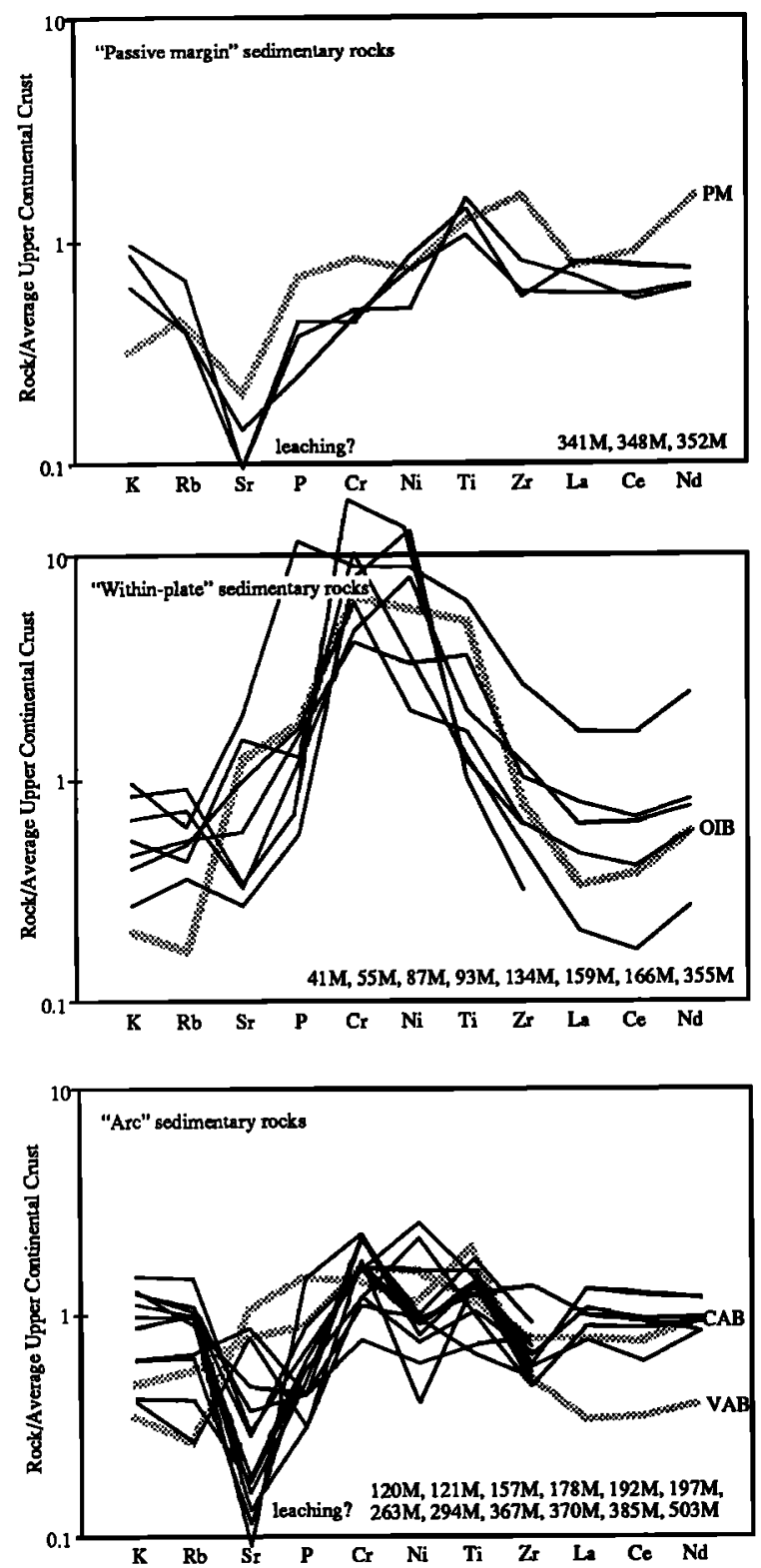

Fig. 4. Abundances of elements in Eastem Hayfork sedimentary rocks normalized to the composition of upper continental crust from Taylor and McLennan [1985]. Average values for sedimentary rocks derived from oceanic island arcs (VAB), continental arcs or active margins (CAB), oceanic within-plate sources (OIB), and passive margins (PM) compiled by Floyd et al. [1991] are shown by heavy shaded lines. Analyzed samples are listed by number in lower right comer and shown by thin solid lines. Elevated $K$ and $R b$ and depleted Sr concentrations probably reflect postdepositional addition and leaching, respectively.

Ti-bearing phase as well. High $\mathrm{Mg}$ numbers in these locally sparsely phyric lavas argue for rapid ascent from the mantle, although the most magnesian (up to $18 \mathrm{wt} \% \mathrm{MgO}$ ) members of the suite contain cumulus homblende \pm clinopyroxene [Hacker et al., 1992].
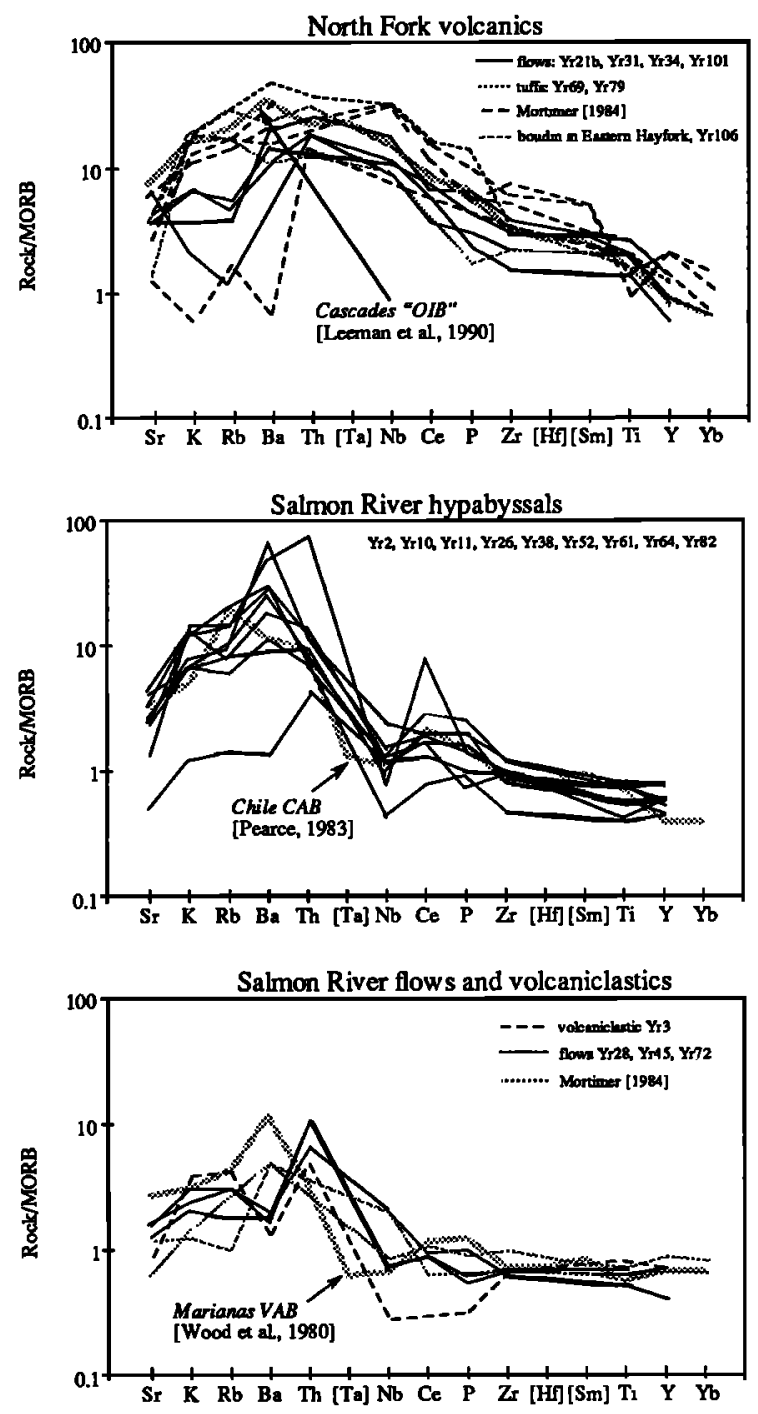

Fig. 5. MORB-normalized abundances of elements in the North Fork unit, Salmon River hypabyssal rocks, and volcanic rocks; gabbroic rocks are excluded. See Ernst et al. [1991] and Emst [in press] for further analyses. Elements shown in parentheses were not analyzed. $\mathrm{Sr}, \mathrm{K}, \mathrm{Rb}$, and $\mathrm{Ba}$ abundances were modified during metamorphism [Hacker et al., 1992] and provide little information about magma chemistry.

Most Salmon River clinopyroxenes are strongly zoned augite and plot within the intraoceanic arc field of Nisbet and Pearce's [1977] discriminant diagram (Figure 6a). Cores are richer in $\mathrm{Cr}_{2} \mathrm{O}_{3}$ than the rims, suggesting that the cores grew while chromite was crystallizing (Figure $6 b$ and $6 c$ ). This trend appears in pyroxene from gabbro, diabase, flow rocks, volcaniclastic rocks, and tuffs. Igneous plagioclase crystals are as calcic as An60 in volcanic rocks and An78 in gabbro.

Plagiogranite within diabase along the Salmon River yielded a strongly discordant $\mathrm{Pb} / \mathrm{U}$ zircon age interpreted by Ando et al. [1983] to indicate crystallization in the range 265310 Ma (Pennsylvanian to Permian). A gabbro body that intrudes the diabase gave a ${ }^{40} \mathrm{Ar} /{ }^{39} \mathrm{Ar}$ isochron age of 200.4 $\pm 1.4 \mathrm{Ma}$ on igneous hornblende (Table 2). As discussed below, hypabyssal rocks intruding the Salmon River unit 

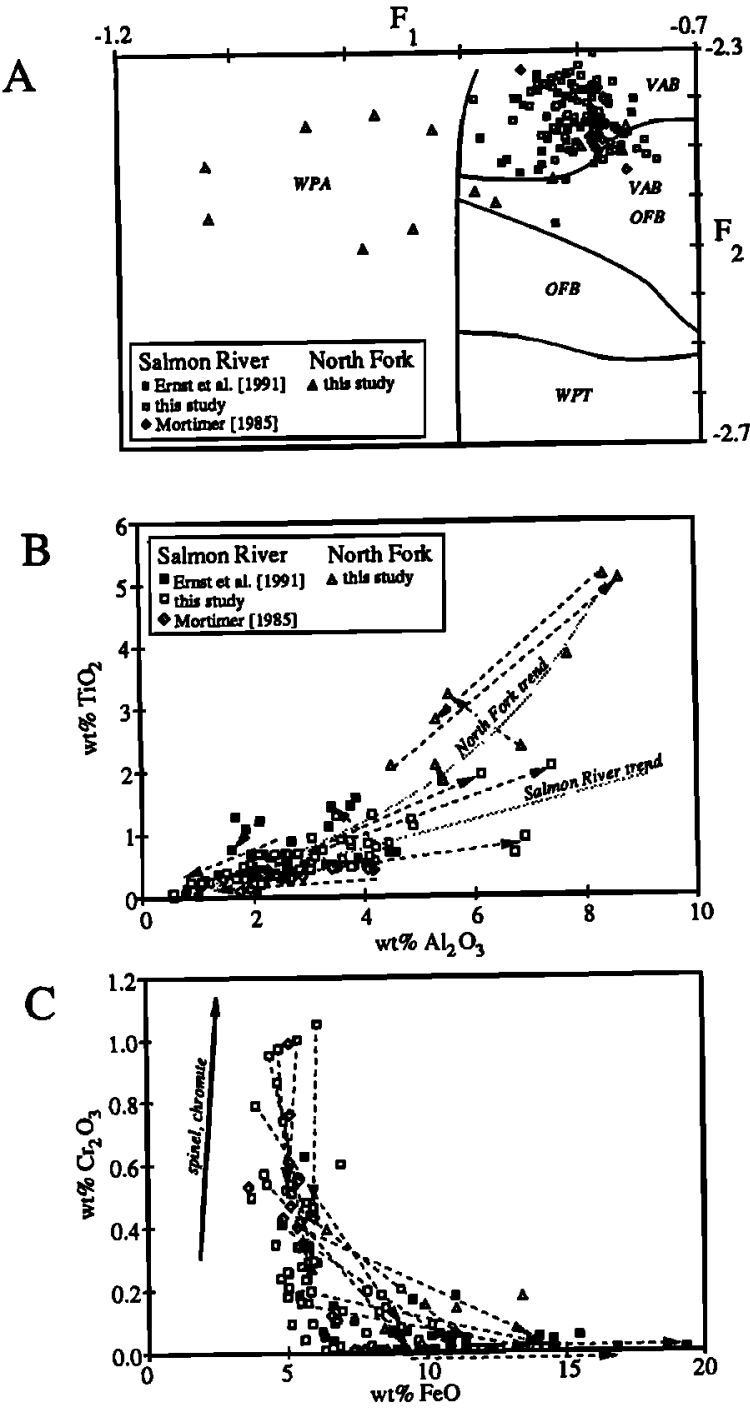

Fig. 6. Salmon River and North Fork clinopyroxene compositions. (a) Discriminant diagram of Nisbet and Pearce [1977]. (b) and (c) Core-to-rim zonation shown by dashed arrows. Note subparallelism of $\mathrm{Cr}$-Fe zoning in $\mathrm{Cr}$-rich pyroxenes to compositional trend of comagmatic spinel and chromite shown by solid arrow in Figure $6 c$.

range in age from $140 \mathrm{Ma}$ to $173 \mathrm{Ma}$. These data could be interpreted to indicate the existence of a PennsylvanianJurassic arc or the presence of a Jurassic arc built on older basement. Fossil ages of interbedded Eastern Hayfork sedimentary rocks suggest that construction of the Salmon River suite began in Permian and extended at least through Late Triassic time.

\section{North Fork Unit}

The North Fork unit comprises up to $2 \mathrm{~km}$ of amygdaloidal volcanic rocks with rare limestone massifs [Ando, 1979; Wright, 1981; Mortimer, 1984]. It has been interpreted to represent a seamount [Davis et al., 1978; Ando, 1979], however, we present an alternative interpretation-that the North Fork is an alkalic part of an immature arc.
The volcanic rocks are massive breccias with angular to subangular clasts, tuffaceous cherts, pillowed flows, pillow breccias, and hyaloclastites. Tuffs are crystal- to lithic-rich with angular to subangular clasts of basaltic rock, plagioclase, and clinopyroxene. The flows are typically aphyric to locally subtrachytic with forsterite + clinopyroxene + plagioclase, plagioclase \pm clinopyroxene, and plagioclase + homblende + clinopyroxene. Preservation of delicate quench textures indicates that deformation was not penetrative and metamorphism was not pervasive. North Fork volcanic rocks are enriched in light rare-earth elements, $\mathrm{P}, \mathrm{Hf}, \mathrm{Zr}, \mathrm{Ta}, \mathrm{Nb}, \mathrm{Fe}$, and Ti relative to mid-ocean ridge basalts, and resemble alkalic ocean-island basalts (OIB) and alkalic anc rocks (Figure 5). Their primitive nature is indicated by $\mathrm{Cr}$ and $\mathrm{Ni}$ contents as high as 600 and $400 \mathrm{ppm}$, respectively. Element-ratio diagrams suggest that clinopyroxene or homblende were fractionating or accumulating phases [Emst et al., 1991]. The lack of an Eu anomaly, high Sr contents, and positive correlations between $\mathrm{Sr}, \mathrm{Zr}$ and $\mathrm{P}$, argue against significant feldspar removal.

Pyroxenes from alkalic rocks tend to have high $\mathrm{Al}_{2} \mathrm{O}_{3}$, $\mathrm{TiO}_{2}$, and $\mathrm{Na}_{2} \mathrm{O}$ contents, and the North Fork pyroxenes are no exception, reaching $>8 \mathrm{wt} \% \mathrm{Al}_{2} \mathrm{O}_{3}, 5 \mathrm{wt} \% \mathrm{TiO}_{2}$, and 0.8 wt\% $\mathrm{Na}_{2} \mathrm{O}$ (Table 3; Figure $6 \mathrm{~b}$ and $6 \mathrm{c}$ ). North Fork pyroxenes are augites and salites higher in $\mathrm{CaO}$ and lower in $\mathrm{SiO}_{2}$ content than Salmon River pyroxenes. As evident in Figure 6a, they straddle the intraoceanic arc and within-plate magma fields in the discrimination diagram of Nisbet and Pearce [1977]. Igneous amphiboles in the North Fork are pargasites and contain more $\mathrm{Na} 2 \mathrm{O}(>3.5 \mathrm{wt} \%)$ and less $\mathrm{TiO}_{2}$ $(\leq 0.3 \mathrm{wt} \%)$ (Table 3 ) than Salmon River homblendes which contain less than $3 \mathrm{wt} \% \mathrm{Na}_{2} \mathrm{O}$ and up to $3 \mathrm{wt} \% \mathrm{TiO}_{2}$ [Ernst et al., 1991].

In the Salmon River area, a single mass of limestone up to $600 \mathrm{~m}$ thick rests depositionally on North Fork volcanic rocks and is overlain by St Claire Creek chert. This thick limestone has a basal conglomerate of basalt and red chert cobbles and contains ooids and sparse volcanic clasts. Elsewhere, limestone beds interlayered with North Fork flows are usually a few meters thick and up to several hundred meters long [Masson, 1949; Trexler, 1968; Hotz, 1977; Ando, 1979]. At some localities, oolitic limestone is intercalated with volcaniclastic rocks and $\propto$ ccurs as interpillow material [Masson, 1949; Ando, 1979; Wright, 1982]. Limestone interbedded with volcanic breccia contains Late Permian algae, foraminifers, and bryozoans characteristic of low-energy, shallow-water normal marine environments [Trexler, 1968; Hotz, 1977; Ando, 1979; Mortimer, 1984]. Subrounded volcanic breccias cemented with calcite suggest subtropical littoral conditions, and lenses of slumped limestone beds within volcanic rocks indicate local topographic relief and unstable carbonate platforms. Limestone beds or exotic(?) blocks contain Late Pennsylvanian-Early Permian, and Early Permian fusulinids, and Early Carboniferous-Permian and Early Permian(?) foraminifers [Irwin, 1972, 1974; Irwin et al., 1977].

Thus far we have been unable to date the crystallization age of the North Fork volcanics using the ${ }^{40} \mathrm{Ar} /{ }^{39} \mathrm{Ar}$ technique because most rocks lack separable $\mathrm{K}$-bearing phases. Sedimentary rocks of the Eastern Hayfork unit interbedded with the North Fork range in age from Late Permian to Late Triassic. Late Permian fossils are present in limestone intercalated with the North Fork volcanics, and the interbedded St Claire Creek unit contains Late Permian to Early or Middle 
TABLE 2a. ${ }^{40} \mathrm{Ar} /{ }^{39} \mathrm{Ar}$ Data for Hornblende

\begin{tabular}{|c|c|c|c|c|c|}
\hline$T$ & $\Sigma{ }^{39} \mathrm{Ar}$ & ${ }^{40} \mathrm{Ar}^{*}$ & ${ }^{37} \mathrm{Ar} /{ }^{39} \mathrm{Ar}$ & ${ }^{40} \mathrm{Ar}^{*} / 39 \mathrm{Ar}^{\mathrm{K}}$ & Age (Ma) $\pm 1 \sigma$ \\
\hline \multicolumn{6}{|c|}{ Sample $Y r 2$} \\
\hline 900 & 0.174 & 0.155 & 2.0285 & 7.4270 & $142.1 \pm 11$ \\
\hline 1000 & 0.202 & 0.280 & 16.8423 & 8.0096 & $152.7 \pm 17$ \\
\hline 1060 & 0.358 & 0.698 & 9.8578 & 7.7114 & $147.3 \pm 3.8$ \\
\hline 1400 & 0.607 & 0.709 & 10.0174 & 8.0404 & $153.3 \pm 3.2$ \\
\hline 1120 & 1.000 & 0.850 & 9.8364 & 7.7374 & $147.8 \pm 2.2$ \\
\hline \multicolumn{6}{|c|}{ Sample Yr13 } \\
\hline 800 & 0.009 & -0.000 & 14.5214 & 1.1564 & $22.5 \pm 296$ \\
\hline 900 & 0.017 & 0.120 & 29.7011 & 8.1060 & $151.8 \pm 59$ \\
\hline 1000 & 0.072 & 0.491 & 20.8547 & 10.2925 & $190.7 \pm 8.1$ \\
\hline 1040 & 0.329 & 0.782 & 17.8869 & 11.0565 & $204.0 \pm 2.8$ \\
\hline 1070 & 0.560 & 0.767 & 21.4978 & 10.7473 & $198.7 \pm 2.5$ \\
\hline 1100 & 0.639 & 0.765 & 19.1293 & 10.3611 & $191.9 \pm 5.2$ \\
\hline 1150 & 0.799 & 0.784 & 20.1233 & 10.8578 & $200.6 \pm 2.9$ \\
\hline 1200 & 0.877 & 0.752 & 21.0896 & 10.7910 & $199.4 \pm 4.9$ \\
\hline 1265 & 0.932 & 0.740 & 22.1728 & 10.9679 & $202.5 \pm 5.7$ \\
\hline 1400 & 1.000 & 0.648 & 21.0959 & 10.5962 & $196.0 \pm 7.4$ \\
\hline \multicolumn{6}{|c|}{ Sample Yr19 } \\
\hline 800 & 0.015 & 0.004 & 2.6058 & 0.6920 & $13.5 \pm 93$ \\
\hline 900 & 0.024 & 0.132 & 4.1571 & 7.6318 & $143.3 \pm 46$ \\
\hline 950 & 0.032 & 0.188 & 7.0100 & 8.3700 & $156.6 \pm 34$ \\
\hline 1000 & 0.042 & 0.231 & 5.0790 & 7.8663 & $147.5 \pm 30$ \\
\hline 1050 & 0.103 & 0.523 & 5.5263 & 8.1627 & $152.9 \pm 6.2$ \\
\hline 1080 & 0.274 & 0.798 & 5.7391 & 8.2472 & $154.4 \pm 2.0$ \\
\hline 1100 & 0.599 & 0.900 & 5.8250 & 8.2249 & $154.0 \pm 0.8$ \\
\hline 1120 & 0.756 & 0.914 & 5.8144 & 8.2411 & $154.3 \pm 1.7$ \\
\hline 1150 & 0.800 & 0.913 & 5.9937 & 8.3934 & $157.0 \pm 5.8$ \\
\hline 1250 & 0.875 & 0.866 & 5.9674 & 8.0532 & $150.9 \pm 2.7$ \\
\hline 1400 & 1.000 & 0.842 & 6.3047 & 8.1595 & $152.8 \pm 3.6$ \\
\hline \multicolumn{6}{|c|}{ Sample Yr45 } \\
\hline 800 & 0.060 & -0.018 & 2.1636 & -3.6753 & $-73.6 \pm 17$ \\
\hline 900 & 0.107 & 0.050 & 1.3526 & 4.4953 & $86.5 \pm 20$ \\
\hline 950 & 0.134 & 0.062 & 6.5079 & 4.8767 & $93.6 \pm 31$ \\
\hline 1000 & 0.159 & 0.096 & 14.1794 & 5.1640 & $98.9 \pm 22$ \\
\hline 1030 & 0.209 & 0.473 & 13.3223 & 7.0614 & $133.9 \pm 12$ \\
\hline 1060 & 0.325 & 0.639 & 14.8268 & 7.1804 & $136.1 \pm 4.2$ \\
\hline 1090 & 0.474 & 0.662 & 15.7687 & 7.5051 & $142.0 \pm 5.1$ \\
\hline 1150 & 0.684 & 0.693 & 16.1946 & 7.5168 & $142.2 \pm 3.0$ \\
\hline 1275 & 0.874 & 0.646 & 18.4827 & 7.4916 & $141.8 \pm 2.9$ \\
\hline 1400 & 1.000 & 0.599 & 11.7967 & 5.8904 & $112.4 \pm 5.4$ \\
\hline \multicolumn{6}{|c|}{ Sample Yr52 } \\
\hline 750 & 0.027 & 0.028 & 2.6867 & 6.2880 & $121.0 \pm 79$ \\
\hline 900 & 0.052 & 0.219 & 3.3491 & 8.2158 & $156.5 \pm 37$ \\
\hline 950 & 0.065 & 0.403 & 8.3738 & 7.4236 & $142.0 \pm 35$ \\
\hline 1000 & 0.086 & 0.439 & 9.4806 & 7.9788 & $152.2 \pm 24$ \\
\hline 1050 & 0.287 & 0.778 & 10.2988 & 7.3489 & $140.6 \pm 3.4$ \\
\hline 1100 & 0.668 & 0.806 & 11.0329 & 7.3294 & $140.3 \pm 2.0$ \\
\hline 1150 & 0.787 & 0.786 & 11.5269 & 7.3769 & $141.1 \pm 5.6$ \\
\hline 1225 & 0.824 & 0.689 & 13.1182 & 6.9650 & $133.6 \pm 15$ \\
\hline 1400 & 1.000 & 0.624 & 12.8426 & 7.3223 & $140.1 \pm 4.6$ \\
\hline \multicolumn{6}{|c|}{ Sample Yr61 } \\
\hline 800 & 0.076 & 0.215 & 2.0189 & 9.1998 & $171.9 \pm 17$ \\
\hline 900 & 0.106 & 0.661 & 1.1537 & 7.8060 & $146.9 \pm 2.5$ \\
\hline 1000 & 0.165 & 0.586 & 7.1922 & 7.4322 & $140.2 \pm 2.3$ \\
\hline 1100 & 0.594 & 0.851 & 7.2564 & 8.1446 & $153.0 \pm 0.8$ \\
\hline 1200 & 0.896 & 0.866 & 7.0350 & 8.1227 & $152.6 \pm 0.6$ \\
\hline 1400 & 1.000 & 0.776 & 8.0608 & 8.1830 & $153.7 \pm 1.7$ \\
\hline
\end{tabular}


TABLE 2a. (continued)

\begin{tabular}{|c|c|c|c|c|c|}
\hline $\mathrm{T}$ & $\Sigma^{39} \mathrm{Ar}$ & ${ }^{40} \mathrm{Ar}^{*}$ & ${ }^{37} \mathrm{Ar} /{ }^{39} \mathrm{Ar}$ & ${ }^{40} \mathrm{Ar}^{*} /{ }^{39} \mathrm{Ar} \mathrm{K}$ & Age (Ma) $\pm 1 \sigma$ \\
\hline \multicolumn{6}{|c|}{ Sample Yr82 } \\
\hline 900 & 0.066 & -0.008 & 20.4592 & -3.0563 & $-60.4 \pm 52$ \\
\hline 1000 & 0.108 & 0.060 & 26.7716 & 7.3956 & $138.2 \pm 29$ \\
\hline 1030 & 0.153 & 0.267 & 13.8804 & 8.8452 & $164.1 \pm 14$ \\
\hline 1070 & 0.267 & 0.705 & 11.4153 & 8.4645 & $157.4 \pm 6.2$ \\
\hline 1100 & 0.397 & 0.703 & 11.5029 & 8.2694 & $153.9 \pm 3.6$ \\
\hline 1200 & 0.777 & 0.685 & 11.8487 & 8.3413 & $155.2 \pm 2.2$ \\
\hline 1300 & 0.893 & 0.591 & 12.2392 & 8.2994 & $154.4 \pm 4.7$ \\
\hline 1400 & 1.000 & 0.400 & 11.1983 & 7.9455 & $148.1 \pm 7.6$ \\
\hline \multicolumn{6}{|c|}{ Sample Yr84 } \\
\hline 800 & 0.039 & 0.034 & 2.8263 & 5.2934 & $100.2 \pm 36$ \\
\hline 900 & 0.082 & 0.527 & 2.0440 & 8.1870 & $152.6 \pm 11$ \\
\hline 950 & 0.109 & 0.594 & 3.1071 & 8.1499 & $152.0 \pm 12$ \\
\hline 1000 & 0.135 & 0.563 & 4.8529 & 7.9139 & $147.8 \pm 11$ \\
\hline 1050 & 0.201 & 0.692 & 11.5377 & 8.3961 & $156.4 \pm 5.1$ \\
\hline 1100 & 0.796 & 0.755 & 14.4726 & 8.8526 & $164.5 \pm 1.7$ \\
\hline 1130 & 0.850 & 0.835 & 12.2150 & 9.0156 & $167.4 \pm 6.7$ \\
\hline 1200 & 0.912 & 0.755 & 13.7384 & 8.6959 & $161.7 \pm 5.1$ \\
\hline 1300 & 0.944 & 0.674 & 12.7120 & 8.5099 & $158.4 \pm 10$ \\
\hline 1400 & 1.000 & 0.616 & 12.9926 & 8.7508 & $162.7 \pm 8.2$ \\
\hline \multicolumn{6}{|c|}{ Sample $220 M$} \\
\hline 900 & 0.134 & 0.019 & 4.6918 & 4.4466 & $84.7 \pm 63$ \\
\hline 1000 & 0.164 & 0.134 & 17.5776 & 6.5700 & $123.8 \pm 63$ \\
\hline 1050 & 0.344 & 0.649 & 12.5937 & 9.1124 & $169.6 \pm 8.6$ \\
\hline 1200 & 0.907 & 0.793 & 13.2877 & 9.3269 & $173.4 \pm 4.2$ \\
\hline 1400 & 1.000 & 0.422 & 14.5766 & 9.2198 & $171.5 \pm 26$ \\
\hline \multicolumn{6}{|c|}{ Sample 448M } \\
\hline 800 & 0.016 & -0.036 & 8.3525 & -25.2326 & $-583.8 \pm 590$ \\
\hline 900 & 0.028 & 0.151 & 11.5948 & 6.2603 & $119.7 \pm 17$ \\
\hline 1000 & 0.079 & 0.256 & 11.5995 & 7.5786 & $143.9 \pm 9.5$ \\
\hline 1050 & 0.281 & 0.763 & 6.7886 & 8.0825 & $153.1 \pm 1.9$ \\
\hline 1100 & 0.516 & 0.825 & 6.5727 & 8.1497 & $154.3 \pm 0.9$ \\
\hline 1200 & 0.886 & 0.816 & 6.6937 & 8.1721 & $154.7 \pm 1.0$ \\
\hline 1400 & 1.000 & 0.704 & 6.8305 & 8.2065 & $155.3 \pm 2.1$ \\
\hline
\end{tabular}

Analytical details are provided by Hacker [1993].

TABLE 2 b. ${ }^{40} \mathrm{Ar} /{ }^{39} \mathrm{Ar}$ Data for Hornblende

\begin{tabular}{lcccccccccc}
\hline Sample & $\mathrm{J}$ & $\begin{array}{c}\text { Weight, } \\
\mathrm{mg}\end{array}$ & $\begin{array}{c}\text { Grain Size, } \\
\mu \mathrm{m}\end{array}$ & $\begin{array}{c}\mathrm{K}_{2} \mathrm{O}, \\
\mathbf{w} \%\end{array}$ & $\begin{array}{c}\text { Total Fusion } \\
\text { Age, Ma }\end{array}$ & $\begin{array}{c}\text { Isochron } \\
\text { Age, Ma }\end{array}$ & $\begin{array}{c}\text { MSWD } \\
\text { Plateau Age, Ma }\end{array}$ & $\begin{array}{c}\text { Weighted Mean } \\
\text { used, }{ }^{\circ} \mathrm{C}\end{array}$ & $\begin{array}{c}39 \text { Ar, } \\
\%\end{array}$ \\
\hline Yr2 & 0.01103200 & 0.3 & 100 & 0.55 & $148.2 \pm 2.4$ & $149.3 \pm 1.7$ & 0.88 & $149.0 \pm 1.6$ & all & 100 \\
Yr13 & 0.01083200 & 5.4 & 200 & 0.30 & $197.6 \pm 2.8$ & $200.4 \pm 1.4$ & 0.83 & $199.8 \pm 1.4$ & all & 100 \\
Yr19 & 0.01083342 & 2.2 & 200 & 0.75 & $151.6 \pm 1.6$ & $154.2 \pm 0.7$ & 0.43 & $153.9 \pm 0.6$ & all & 100 \\
Yr45 & 0.01091362 & 3.2 & 80 & 0.30 & $120.0 \pm 2.2$ & $142.6 \pm 1.7$ & 0.55 & $142.0 \pm 1.9$ & $1090-1275$ & 55 \\
Yr52 & 0.01103186 & 1.8 & 80 & 0.55 & $140.3 \pm 2.9$ & $140.5 \pm 1.6$ & 0.11 & $140.4 \pm 1.5$ & all & 100 \\
Yr61 & 0.01086971 & 2.0 & 200 & 0.80 & $153.5 \pm 1.4$ & $153.1 \pm 1.5$ & 7.1 & $152.8 \pm 0.5$ & $1100-1400$ & 98 \\
Yr82 & 0.01076969 & 0.9 & 80 & 0.40 & $140.6 \pm 3.7$ & $155.9 \pm 1.6$ & 0.35 & $154.7 \pm 1.6$ & $1000-1400$ & 93 \\
Yr84 & 0.01078490 & 2.4 & 200 & 0.45 & $159.9 \pm 2.0$ & $163.8 \pm 1.5$ & 0.71 & $164.2 \pm 1.5$ & $1100-1400$ & 80 \\
$220 M$ & 0.01081600 & 0.4 & 400 & $\ldots$ & $159.4 \pm 9.2$ & $173.2 \pm 3.7$ & 0.17 & $172.5 \pm 3.7$ & $1000-1400$ & 87 \\
$448 M$ & 0.01095683 & 1.3 & 100 & $\ldots$ & $144 \pm 6.2$ & $155.5 \pm 0.7$ & 2.1 & $154.4 \pm 0.6$ & $1000-1400$ & 97 \\
\hline
\end{tabular}

$\mathrm{J}$, irradiation parameter; MSWD, mean sum of weighted deviates of isochron; isochron and weighted mean plateau ages are based on temperature steps and fraction of ${ }^{39} \mathrm{Ar}$ listed in the last two columns. 
TABLE 3. North Fork Igneous Pyroxene and Hornblende Compositions

\begin{tabular}{|c|c|c|c|c|c|c|}
\hline & \multicolumn{6}{|c|}{ Sample/Analysis } \\
\hline & Yr51/62 & r51/62 & r $51 / 65$ & Yr51/66 & Yr51/67 & Yr51/68 \\
\hline & rim & core & core & core & core & core \\
\hline & \multicolumn{6}{|c|}{ Pargarite } \\
\hline $\mathrm{SiO}_{2}$ & 39.92 & 42.77 & 41.91 & 41.55 & 40.41 & 41.22 \\
\hline $\mathrm{Al}_{2} \mathrm{O}_{3}$ & 14.95 & 12.90 & 13.40 & 13.51 & 16.18 & 14.24 \\
\hline $\mathrm{TiO}_{2}$ & 0.30 & 0.22 & 0.17 & 0.25 & 0.18 & 0.23 \\
\hline $\mathrm{FeO} *$ & 18.87 & 16.77 & 17.88 & 17.45 & 17.34 & 17.63 \\
\hline $\mathrm{Cr}_{2} \mathrm{O}_{3}$ & 0.07 & 0.04 & 0.05 & 0.04 & 0.09 & 0.00 \\
\hline $\mathrm{MnO}$ & 0.24 & 0.27 & 0.26 & 0.26 & 0.28 & 0.30 \\
\hline $\mathrm{MgO}$ & 8.04 & 9.75 & 9.46 & 9.47 & 8.28 & 8.66 \\
\hline $\mathrm{CaO}$ & $11.09^{\circ}$ & 11.44 & 11.39 & 11.68 & 10.88 & 11.34 \\
\hline $\mathrm{Na}_{2} \mathrm{O}$ & 4.03 & 3.70 & 3.82 & 3.85 & 3.88 & 3.83 \\
\hline $\mathrm{K}_{2} \mathrm{O}$ & 0.46 & 0.36 & 0.36 & 0.40 & 0.38 & 0.39 \\
\hline Sum & 97.95 & 98.23 & 98.73 & 98.46 & 97.91 & 97.84 \\
\hline $\mathbf{S i}$ & 6.05 & 6.39 & 6.25 & 6.24 & 6.05 & 6.22 \\
\hline $\mathrm{Al}^{\mathrm{IV}}$ & 1.95 & 1.61 & 1.75 & 1.76 & 1.95 & 1.78 \\
\hline $\mathrm{Al}^{\mathrm{VI}}$ & 0.72 & 0.67 & 0.61 & 0.63 & 0.91 & 0.76 \\
\hline $\mathrm{Ti}$ & 0.03 & 0.02 & 0.02 & 0.03 & 0.02 & 0.03 \\
\hline $\mathrm{Cr}$ & 0.01 & 0.01 & 0.01 & 0.01 & 0.01 & 0.00 \\
\hline $\mathrm{Fe}^{2+}$ & 2.36 & 2.09 & 2.20 & 2.18 & 2.14 & 2.22 \\
\hline $\mathbf{M n}$ & 0.03 & 0.03 & 0.03 & 0.03 & 0.04 & 0.04 \\
\hline $\mathbf{M g}$ & 1.82 & 2.17 & 2.10 & 2.12 & 1.85 & 1.95 \\
\hline Sum & 4.97 & 4.99 & 4.97 & 4.99 & 4.97 & 4.99 \\
\hline $\mathrm{Ca}$ & 1.80 & 1.83 & 1.82 & 1.88 & 1.75 & 1.83 \\
\hline $\mathrm{Na}$ & 1.18 & 1.07 & 1.11 & 1.12 & 1.13 & 1.12 \\
\hline $\mathbf{K}$ & 0.09 & 0.07 & 0.07 & 0.08 & 0.07 & 0.08 \\
\hline
\end{tabular}

Jurassic fossils. The oldest pluton intruding the North Fork is the English Peak pluton ( $\geq 164 \mathrm{Ma} \mathrm{Pb} / \mathrm{U}$ zircon age; Wright and Fahan [1988]). Thus, eruption may have spanned Late Permian to Middle Jurassic time.

Although the North Fork rocks are alkalic ocean-island basalts, they need not represent seamounts. They may have erupted within the same immature arc as the Salmon River unit because the two units interfinger and are permissibly coeval [Emst, 1990]. Alkaline magmas with high-field strength element enrichment were initially thought to be restricted to within-plate magmas generated deep in the mantle. It is now recognized that such volcanic rocks occur in a variety of settings, including intraoceanic and continental margin arcs; in some arcs they are even the dominant rock type [e.g., Leeman et al., 1990]. Moreover, OIB-like rocks within arcs may be related to subduction of young lithosphere. Storey et al. [1989] proposed that when a no-slab window appeared beneath Baja California following ridge subduction, OIBs were erupted because of the anomalously shallow heat. Ormerod et al. [1988] noted that OIB lavas were erupted in the westem Basin and Range Province 2-3 m.y. after the trailing edge of subducted Pacific lithosphere passed beneath, leaving a no-slab window. The Washington Cascades arc is locally dominated by OIBs, perhaps produced because the lithosphere being subducted is young and hot and may devolatilize before reaching depths of magma generation, preventing both metasomatism of the mantle wedge and the development of a normal arc signature [Leeman et al., 1990]. Thus, the North Fork rocks, which appear to be an integral part of an immature arc, may also have erupted following ridge subduction.

TABLE 3. Sample/Analysis continued

\begin{tabular}{|c|c|c|c|c|c|c|c|c|c|c|c|c|}
\hline & $\begin{array}{l}\mathrm{r} 18 / 4 \\
\text { core }\end{array}$ & $\begin{array}{c}\text { Yr18/4 } \\
\text { rim }\end{array}$ & $\begin{array}{c}\mathrm{Yr} 18 / 4 \\
\text { core }\end{array}$ & $\begin{array}{c}\text { Yr18/5 } \\
\text { rim }\end{array}$ & $\begin{array}{c}\text { Yr51/5 } \\
\text { core }\end{array}$ & $\begin{array}{c}\text { Yr51/6 } \\
\text { rim }\end{array}$ & $\begin{array}{c}\text { Yr } 51 / 6 \\
\text { core }\end{array}$ & 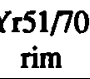 & $\begin{array}{c}\text { Yr15/2 } \\
\text { core }\end{array}$ & $\begin{array}{c}\text { Yr15/2 } \\
\text { rim }\end{array}$ & core & $\begin{array}{c}\text { Yr15/3 } \\
\text { rim }\end{array}$ \\
\hline & \multicolumn{12}{|c|}{ Pyroxene } \\
\hline $\mathrm{SiO}_{2}$ & 49.23 & 48.68 & 47.89 & 48.07 & 42.47 & 47.07 & 48.72 & 42.84 & 51.76 & 53.56 & 50.08 & 50.79 \\
\hline $\mathrm{Al}_{2} \overline{\mathrm{O}}_{3}$ & 5.45 & 5.32 & 6.85 & 5.57 & 8.38 & 5.32 & 4.51 & 8.66 & 3.03 & 1.62 & 4.01 & 3.58 \\
\hline $\mathrm{TiO}_{2}$ & 1.80 & 2.06 & 2.35 & 3.19 & 5.11 & 2.80 & 2.06 & 5.05 & 0.58 & 0.30 & 1.00 & 0.90 \\
\hline $\mathrm{FeO}^{*}$ & 13.64 & 11.26 & 8.68 & 10.16 & 9.91 & 9.53 & 8.68 & 10.93 & 6.66 & 6.08 & 8.44 & 8.78 \\
\hline $\mathrm{Cr}_{2} \mathrm{O}_{3}$ & 0.18 & 0.14 & 0.08 & 0.15 & 0.58 & $<$ & $<$ & $<$ & 0.40 & 0.27 & $<$ & $<$ \\
\hline $\mathrm{MnO}$ & 0.37 & 0.28 & 0.21 & 0.24 & 0.09 & $<$ & 0.18 & 0.23 & 0.16 & 0.18 & 0.71 & 0.31 \\
\hline $\mathrm{MgO}$ & 11.41 & 13.93 & 14.26 & 13.10 & 10.82 & 12.29 & 14.04 & 10.36 & 17.76 & 18.29 & 15.08 & 16.31 \\
\hline $\mathrm{CaO}$ & 14.46 & 17.29 & 18.47 & 19.28 & 21.84 & 21.27 & 21.23 & 20.45 & 18.35 & 19.05 & 20.19 & 19.25 \\
\hline $\mathrm{Na}_{2} \mathrm{O}$ & 2.81 & 0.51 & 0.48 & 0.51 & 0.56 & 0.49 & 0.62 & 0.82 & 0.22 & 0.14 & 0.27 & 0.20 \\
\hline $\mathrm{K}_{2} \mathrm{O}$ & $<$ & $<$ & $<$ & $<$ & $<$ & $<$ & $<$ & $<$ & $<$ & $<$ & $<$ & $<$ \\
\hline Sum & 99.36 & 99.46 & 99.26 & 100.3 & 99.76 & 98.77 & 100.1 & 99.34 & 98.92 & 99.50 & 99.78 & 100.1 \\
\hline $\mathrm{Si}$ & 1.87 & 1.83 & 1.79 & 1.80 & 1.63 & 1.80 & 1.82 & 1.65 & 1.91 & 1.96 & 1.87 & 1.88 \\
\hline $\mathrm{Al}^{\mathrm{IV}}$ & 0.13 & 0.17 & 0.21 & 0.20 & 0.37 & 0.20 & 0.18 & 0.35 & 0.09 & 0.04 & 0.13 & 0.12 \\
\hline $\mathrm{Al}^{\mathrm{VI}}$ & 0.11 & 0.07 & 0.09 & 0.04 & 0.01 & 0.03 & 0.02 & 0.04 & 0.05 & 0.03 & 0.05 & 0.04 \\
\hline $\mathrm{Ti}$ & 0.05 & 0.06 & 0.07 & 0.09 & 0.15 & 0.08 & 0.06 & 0.15 & 0.02 & 0.01 & 0.03 & 0.02 \\
\hline $\mathrm{Cr}$ & 0.01 & 0.00 & 0.00 & 0.00 & 0.02 & $<$ & $<$ & $<$ & 0.01 & 0.01 & $<$ & $<$ \\
\hline $\mathrm{Fe}^{2+}$ & 0.43 & 0.35 & 0.27 & 0.32 & 0.32 & 0.30 & 0.27 & 0.35 & 0.21 & 0.19 & 0.26 & 0.27 \\
\hline Mn & 0.01 & 0.01 & 0.01 & 0.01 & 0.00 & $<$ & 0.01 & 0.01 & 0.01 & 0.01 & 0.02 & 0.01 \\
\hline Mg & 0.65 & 0.78 & 0.79 & 0.73 & 0.62 & 0.70 & 0.78 & 0.59 & 0.98 & 1.00 & 0.84 & 0.90 \\
\hline $\mathrm{Ca}$ & 0.59 & 0.70 & 0.74 & 0.77 & 0.90 & 0.87 & 0.85 & 0.84 & 0.73 & 0.75 & 0.81 & 0.76 \\
\hline Sum & 1.85 & 1.97 & 1.97 & 1.96 & 2.02 & 1.99 & 1.98 & 1.98 & 2.01 & 2.00 & 2.01 & 2.00 \\
\hline $\mathrm{Na}$ & 0.21 & 0.04 & 0.03 & 0.04 & 0.04 & 0.04 & 0.05 & 0.06 & 0.02 & 0.01 & 0.02 & 0.01 \\
\hline $\mathbf{K}$ & $<$ & $<$ & $<$ & $<$ & $<$ & $<$ & $<$ & $<$ & $<$ & $<$ & $<$ & $<$ \\
\hline
\end{tabular}

Less than signs denote compositions below detection. Sum refers to $\mathrm{Al}^{\mathrm{VI}}+\mathrm{Ti}+\mathrm{Cr}+\mathrm{Fe}+\mathrm{Mn}+\mathrm{Mg}$ for amphibole and $\mathrm{Al}^{\mathrm{VI}}+\mathrm{Ti}+\mathrm{Cr}+\mathrm{Fe}+\mathrm{Mn}+\mathrm{Mg}+\mathrm{Ca}$ for pyroxene. Analytical details are provided by Hacker et al. [1992]. 


\section{St Claire Creek Unit}

This unit, informally named after exposures along the South Fork of the Salmon River near St Claire Creek, comprises chiefly coherent, bedded chert and minor argillite [Ando, 1979; Wright, 1981; Mortimer, 1984] unlike the disrupted, argillite-dominated sequences of the Eastem Hayfork unit. Previously it was included as part of the North Fork terrane, and postulated to represent open-ocean sediments [Davis et al., 1978; Ando, 1979; Wright, 1982], but herein we separate this sediment-dominated unit from the alkalic volcanic rocks of the North Fork. The new name emphasizes that the Salmon River and North Fork are interbedded with two distinctly different types of sedimentary rock: disrupted chertargillite of the Eastem Hayfork and coherent, well-bedded chertargillite of the St Claire Creek unit.

St Claire Creek chert contains radiolarians, sponge spicules, fragments of plagioclase, quartz, clinopyroxene, brown homblende, chlorite, muscovite, and carbonaceous material [Cox and Pratt, 1973; Wright, 1981]. Radiolarians and sponge spicules in chert have shape-preferred orientations suggesting deposition by currents [Mortimer, 1984]. Sandstone and argillite turbidites interlayered with the chert contain crystals of quartz, plagioclase, and rare potassium feldspar, and clasts of argillite, chert, recrystallized chert, mica schist, volcanic rock, and Permian McCloud limestone [Fahan, 1982; Wright, 1982; Gray, 1986]. Chert contains Paleozoic, Late Permian, Middle Triassic, Late Triassic to Early Jurassic, and Early to Middle Jurassic radiolarians, and Middle Permian and Late Triassic conodonts [Irwin et al., 1977, 1982; Blome and Irwin, 1983; Mortimer, 1984]. The composition of the detritus indicates that the undisrupted chert-argillite of the St Claire Creek unit was derived from sources similar to those providing sediment to the Eastem Hayfork unit [Wright, 1982]. The St Claire Creek unit is also largely coeval with the Eastem Hayfork and North Fork-Salmon River units.

\section{Stuart Fork Terrane}

The Stuart Fork terrane, metamorphosed in Late Triassic time (two $\mathrm{K} / \mathrm{Ar}$ ages and one ${ }^{40} \mathrm{Ar} /{ }^{39} \mathrm{Ar}$ age on phengite average $\sim 219 \mathrm{Ma}$ ), is a blueschist-facies broken formation comprising hemipelagic shale, chert, and mafic volcanic rocks [Hotz 1977; Hotz et al., 1977]. Detrital feldspars in the metasedimentary rocks indicate proximity to a craton or magmatic arc. The volcanic rocks are chiefly massive and locally amygdaloidal pillowed flow rocks with interpillow carbonate. Trace element abundances suggest that the Stuart Fork volcanics are back-arc basin basalts [Goodge, 1990].

Submarine low-pressure metamorphism of the Stuart Fork terrane was followed by blueschist and eclogite formation. Eclogites suggest metamorphic conditions of 900-1100 MPa and $300^{\circ}-400^{\circ} \mathrm{C}$ [Borns, 1980,1984$]$, and blueschist-facies recrystallization occurred at $500-900 \mathrm{MPa}$ and $250^{\circ}-400^{\circ} \mathrm{C}$ [Goodge, 1989a, 1989b; Hacker and Goodge, 1990].

\section{TIES BETWEEN UNITS}

Although Irwin [1972] initially postulated that Klamath terranes might be unrelated far-traveled entities, more data led to the suggestion that the terranes were related to one another [Davis et al., 1978]. Demonstrated interrelationships among Klamath terranes have strengthened with time. An early proposal that the St Claire Creek and Stuart Fork terranes are correlated [Davis and Lipman, 1962] has been discounted [Wright, 1982] because, although older rocks in the St Claire Creek could be equivalent to Stuart Fork prowliths, radiolarians in the St Claire Creek postdate metamorphism of the Stuart Fork. Lithologic similarities shared by sedimentary rocks of the Eastern Hayfork and St Claire Creek units led Ando et al. [1977] to propose stratigraphic equivalence of these two units.

Many of the contacts between the Eastem Hayfork, North Fork, Salmon River, St Claire Creek, and Stuart Fork units are faults formed during Middle Jurassic deformation [Wright and Fahan, 1988]. Accordingly, these units have been regarded as terranes. However, not all contacts between the units are tectonic, and the primary nature of some contacts is locally preserved. The two extensive volcanoplutonic units, the Salmon River tholeiitic suite and North Fork alkalic suite, interfinger and are permissibly coeval, indicating that they are part of the same magmatic arc [Emst, 1990].

The contact between the Eastern Hayfork and North ForkSalmon River units is interpreted as the complex zone between an accretionary complex (Eastern Hayfork) and an immature magmatic arc (North Fork-Salmon River), as illustrated in Figure 7. Parts of this zone show depositional contacts and parts are faults [Emst, 1990]. Some of these faults may be syndepositional while others cut all observable bedding. Gradational sequences of basal pillowed flows, overlying volcaniclastic rocks, argillite and chert are characteristic of contacts where the North Fork-Salmon River volcanics overlie Eastern Hayfork sedimentary rocks. These sequences are inverted where the Eastern Hayfork unit overlies the North Fork and Salmon River units. Crystal- to lithic-rich tuffs of the North Fork-Salmon River suite are also interbedded with radiolarian-bearing argillite and chert of the Eastern Hayfork unit. These depositional contacts are observed in the Sawyers Bar and Yreka areas. Furthermore, trace element abundances suggest that argillite of the Eastern Hayfork interbedded with the North Fork-Salmon River volcanics received detritus from a magmatic arc-implying that the North Fork-Salmon River arc was active during deposition of the accretionary wedge. All the "within-plate" Eastern Hayfork sedimentary rocks (Figure 4) were collected near North Fork volcanic rocks (which have

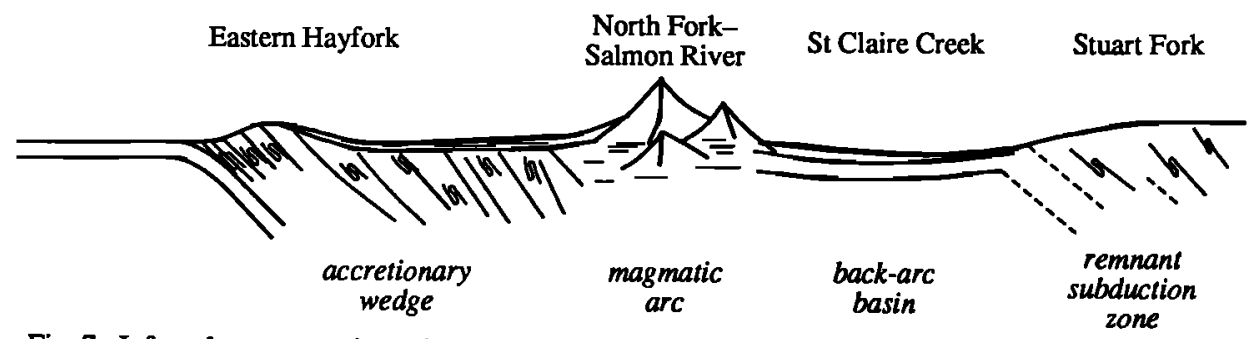

Fig. 7. Inferred petrotectonic setting of the North Fork-Salmon River arc and associated sedimentary deposits in Jurassic time. 
alkalic within-plate trace-element signatures), and all the "arc" or "passive margin" sedimentary rocks crop out near Salmon River volcanic rocks (which represent a tholeiitic immature arc). This implies that interlayered volcanic and sedimentary rocks in the Sawyers Bar area were derived from the same source. Boudinaged hypabyssal North-Fork-affinity dikes intrude the Eastern Hayfork accretionary complex.

The St Claire Creek and North Fork units are also interbedded. Along the Salmon River, North Fork limestone is overlain by bedded red chert that passes upward into gray chert of the St Claire Creek unit. Where the limestone is not present, red chert lies directly on North Fork basalt and forms lenses between pillows [Wright, 1981; Ando et al., 1983]. Sedimentological features mentioned earlier indicate that the undisrupted chert-argillite St Claire Creek unit and the disrupted chert-argillite Eastem Hayfork unit were derived from similar sources [Wright, 1981] and are coeval.

Previous maps have shown large exposures of undisrupted alkalic volcanic rocks in the Eastern Hayfork [e.g., Mortimer, 1985], and disrupted chert-argillite units in the North Fork and Salmon River units [e.g., Ando et al., 1983; Mortimer, 1985]. We prefer to include all intact alkalic volcanic rocks in the North Fork unit, and all disrupted chert-argillite rocks in the Eastem Hayfork. This subdivision, based on lithologies, rather than on groupings of unlike rock types is necessary because there is no basis for distinguishing disrupted chertargillite in one area (associated with alkalic North Fork rocks, say) from chert-argillite in another area (associated with tholeiitic Salmon River rocks, for example).

\section{LATE JURASSIC-EARLY CRETACEOUS DIKES}

In an attempt to measure eruption ages of the North Fork and Salmon River units, we determined ${ }^{40} \mathrm{Ar} /{ }^{39} \mathrm{Ar}$ ages of hornblendes from nine mafic hypabyssal dikes/sills and one gabbro (Figure 8; Table 2). The samples were selected because they contain relatively fresh hornblende and yet appear to have been metamorphosed to the same facies as the host rocks because they contain metamorphic quartz, albite, epidote, calcite, and trace actinolite. All analyzed dikes have tholeiitic bulk compositions similar to the Salmon River suite, except for Yr84, which is alkalic. Except for the gabbro, all the dated rocks are rapidly cooled diabases that were never metamorphosed above greenschist-facies conditions $\left(\leq 400^{\circ} \mathrm{C}\right.$; Hacker et al. [1992]); thus each age spectrum should be dominated by a plateau that reflects the time elapsed since igneous crystallization. In general, the Ar/Ar spectra obtained do have simple plateaus. There are no indications of excess Ar in the release spectra, and isochrons do not reveal trapped nonatmospheric Ar. The exception is sample Yr45, which has an age spectrum suggesting $-20 \%$ argon loss and for which isochron analysis yields a nonatmospheric ${ }^{40} \mathrm{Ar} /{ }^{36} \mathrm{Ar}$ ratio.

Most of the intrusive samples proved to be surprisingly young in spite of the fact that they have metamorphic parageneses similar to the enclosing country rocks. The broadly 300-Ma zircon date from Salmon River plagiogranite [Ando et al., 1983], the 159-164 Ma age of the cross-cutting Wooley Creek calc-alkaline plutonic suite (Russian Peak and English Peak plutons; Wright and Fahan [1988]), and the Permian to Jurassic ages of interbedded chert, led us to expect ages in the range 160-300 Ma. Three of the samples yielded ages that predate the 161-Ma-old Wooley Creek granitoids and thus are plausible eruption ages. Most of the dikes, however, are younger than the Wooley Creek suite and range in age from 156-140 Ma (Table 2). This has two significant implications.

1. The dikes share the same grade of metamorphism as their host rocks, hence the latter must have been relatively warm at the time of hypabyssal intrusion because the dikes/sills are spaced at least $100 \mathrm{~m}$ apart and would have cooled too rapidly for significant autometamorphism if intruded into cold wall rock. Metamorphism of the country rock, commonly considered to be mid-Jurassic [Coleman et al., 1988], thus probably lasted into Early Cretaceous time [cf. Harper and Wright, 1984], albeit at rather low temperatures. Additional evidence for significant heat retention into Cretaceous time comes from the Condrey Mountain terrane (Figure 1), which yielded muscovite $\mathrm{K} / \mathrm{Ar}$ ages of $125-143 \mathrm{Ma}$ and Rb-Sr isochron ages of 125-139 Ma [Helper et al., 1989].

2. Tholeiitic arc magmatism continued in the central California Klamaths from $\sim 200 \mathrm{Ma}$ to $\sim 140 \mathrm{Ma}$. This activity may be a continuum but can be partitioned for the sake of discussion into $\sim 200 \mathrm{Ma}, \sim 175 \mathrm{Ma}, \sim 164 \mathrm{Ma}, \sim 155 \mathrm{Ma}, \sim 149$ $\mathrm{Ma}$, and $~ 140-\mathrm{Ma}$-old magmatic suites.

The youngest ages come from dikes (samples Yr45 and Yr52) intruding the Salmon River and North Fork units west of Yreka (Figure 2). The age of $140.5 \pm 1.6 \mathrm{Ma}$ likely reflects crystallization of dike Yr52, but the disturbed Ar isotopic systematics of dike Yr45 suggest that $142.6 \pm 0.7 \mathrm{Ma}$ is a (probably small) underestimate of the crystallization age. These diabases are probably the same suite of undeformed but weakly metamorphosed dikes and sills in the southern and central Klamaths that Fahan [1982] and Wright and Fahan [1988] dated by K/Ar method on homblende as ranging from 134 to $141 \mathrm{Ma}$. They are also the same age as numerous plutons in the Klamaths (Coon Mountain, Jacksonville, Gold Hill, Sugar Pine, White Rock, Grants Pass) [Lanphere et al., 1968; Hotz, 1971; Saleeby et al., 1982].

A slightly older (149.3 $\pm 1.7 \mathrm{Ma})$ metadiabase dike (sample Yr2) was collected from the Salmon River unit near the Trinity River. Igneous rocks of this age are widespread in the Klamath Mountains. Late Jurassic $(149 \pm 6 \mathrm{Ma}$; K/Ar on six bulk-rock samples) immature-arc volcanic rocks intrude the Trinity terrane [Brouxel et al., 1989], and plutons with $149 \pm 2$ $\mathrm{Ma} \mathrm{Pb} / \mathrm{U}$ ages intrude the Galice Formation [Ammon Ridge and Glenn Creek plutons; Wright and Fahan [1988]) and Preston Peak ophiolite (Bear Mountain intrusive complex; Saleeby et al. [1982]).

Four mafic dikes yielded mid-150-Ma ages similar to the Ashland pluton [concordant $155 \mathrm{Ma} \mathrm{K} / \mathrm{Ar}$ ages on homblende and biotite; P. R. Renne personal communication, 1991]. Sample Yr19 from the North Fork unit gave an age of 154.2+0.7 Ma, sample 448 $\mathrm{M}$ intruding the Salmon River terrane yielded an age of $155.5 \pm 0.7 \mathrm{Ma}$, sample Yr61 cutting the Eastern Hayfork terrane has an age of $153.1 \pm 1.5 \mathrm{Ma}$, and sample Yr82 from the Stuart Fork terrane gave an age of $155.9 \pm 1.6 \mathrm{Ma}$. These samples are $\sim 30$ and $-60 \mathrm{~km}$ south of the Ashland pluton, however, indicating that the $\sim 155$-Ma-old magmatism was widespread.

A 163.8 $\pm 1.5 \mathrm{Ma}$ age was obtained for an alkalic dike (sample Yr84) in the North Fork unit. This rock is similar in age to the widespread Wooley Creek plutonic suite (159-164 Ma; Barnes et al. [1986], Wright and Fahan [1988]) which intrudes the Rattlesnake Creek, Westem Hayfork, Eastern Hayfork, Salmon River, Stuart Fork, and Central Metamorphic units.

The only rocks believed to represent part of the Salmon River suite are 220M, a metadiabase that yielded an age of 173 $\mathrm{Ma}$, and Yr13, a gabbro dated as $200 \mathrm{Ma}$.

\section{DEFORMATION}

Subhorizontal contraction of the Eastem Hayfork, North Fork, Salmon River, St Claire Creek, and Stuart Fork units 

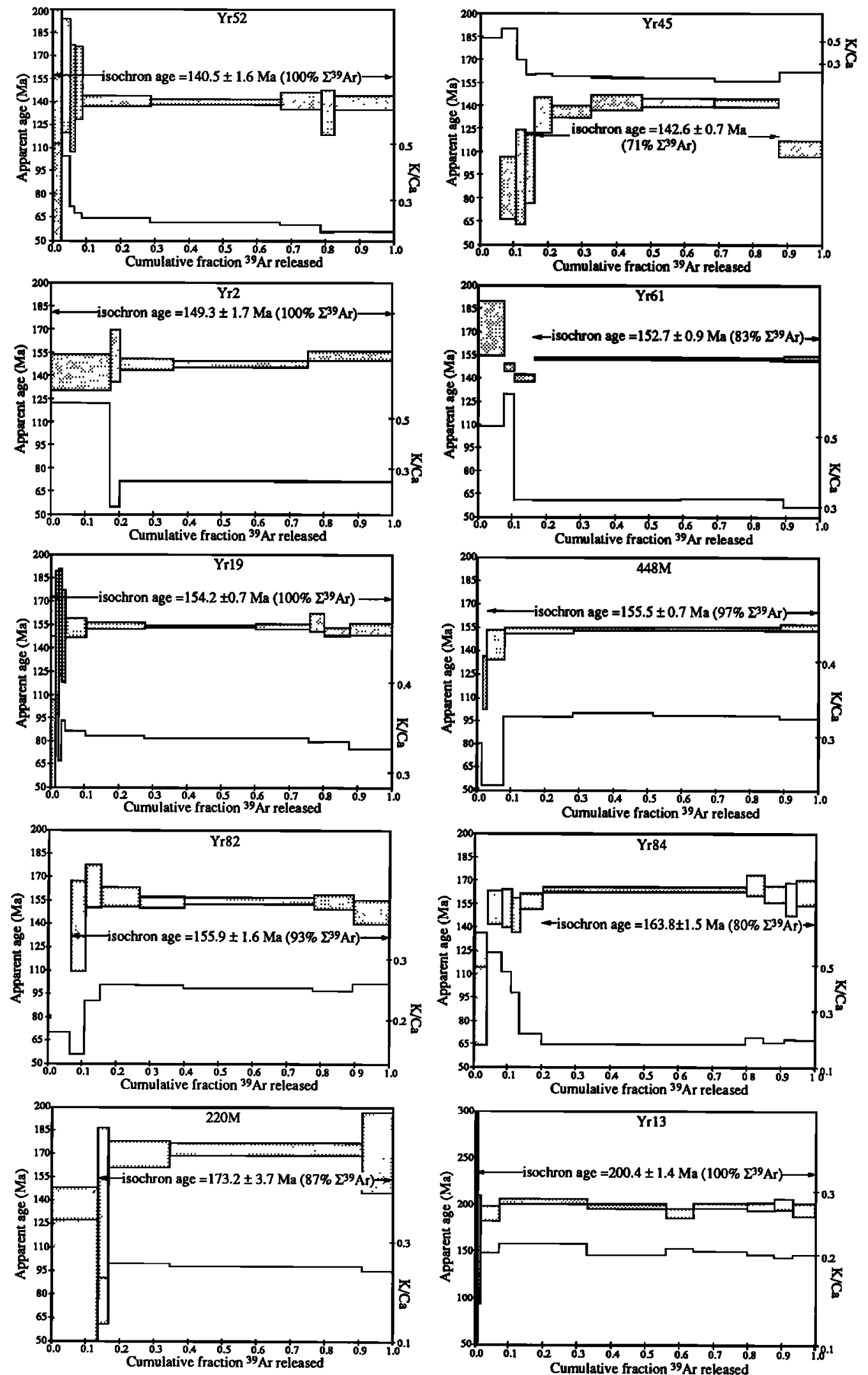

Fig. $8 .{ }^{40} \mathrm{Ar} /{ }^{39} \mathrm{Ar}$ and $\mathrm{K} / \mathrm{Ca}$ spectra of dated samples. One standard deviation uncertainties are shown. 
occurred early in the time period 170-161 Ma (probably preEnglish Reak pluton, $\mathrm{Pb} / \mathrm{U}$ age of $\geq 164 \mathrm{Ma}$; Bames et al. [1986], Wright and Fahan [1988], Harper et al. [1993]). Isoclinal folds are evident in sedimentary rocks but poorly developed in massive igneous rocks [Cashman, 1979; Charlton, 1979; Mortimer, 1985; Goodge, 1989a].

Younger normal faults, including the Scott Valley, Browns Meadow and Vesa Bluffs faults, expose different levels of the North Fork-Salmon River arc (Figure 1). Northeast of the Scott Valley fault, metamorphic grade is subgreenschist facies, relict igneous textures are well preserved, and "higher-level" rocks such as pillowed flows and volcaniclastic rocks predominate; south of the fault, metamorphic grade locally reaches upper greenschist facies, relict igneous textures are rare, and "medium-level" rocks including massive volcanic rocks and dikes/sills predominate. "Deep-level" rocks such as gabbro and ultramafic rocks are more abundant south of the Browns Meadow fault. The Vesa Bluffs fault exposes the structurally deeper Rattlesnake Creek and Salmon River units north of the fault, and structurally higher Eastem Hayfork and North Fork units to the south. The northward decrease in structural level north of Vesa Bluffs fault suggests that another east-west trending, south dipping normal fault may have been present, and was intruded by the Ashland pluton. Except for the Vesa Bluffs fault, which must predate the Vesa Bluffs

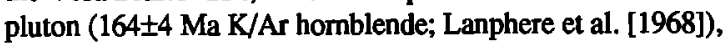
younger age constraints on high-angle normal faulting are not available.

Cox [1956], Ando [1979], and Ando et al. [1983] suggested that the North Fork, Salmon River, and Eastern Hayfork units describe an antiform, based principally on the outcrop pattern of lithologies in the Salmon River unit and the postulated existence of blueschists on both limbs of the antiform. However, both of these assumptions are questionable. The outcrop pattern of igneous rocks in the core of the alleged antiform probably reflects the nonplanar nature of intrusive contacts and not folding. The blueschist unit on the west limb of the antiform within the Eastem Hayfork has been located in different areas along the Salmon-Trinity divide in two maps [Ando et al., 1977; Davis et al., 1980]. Both localities were investigated in reconnaissance by B. R. Hacker and J. W. Goodge in 1990; although blue slates crop out in both areas, no sodic-amphibole-bearing rocks are present. Moreover, Cashman [1979] and Ando et al. [1977] stated that blueschist float, only, has been recovered from Hotaling Creek draining the Salmon-Trinity divide. Substantial outliers of the Stuart Fork terrane (up to $>10 \mathrm{~km}^{2}$ ) occur within the North Fork and Eastern Hayfork (this study; Figure 2), and blueschist blocks or olistoliths occur within the Eastern Hayfork near the Trinity River [Cox, 1956; Fahan, 1982], but we question the existence of a mappable Eastem Hayfork blueschist unit west of the North Fork-Salmon River arc.

\section{METAMORPHISM}

Because of their proximity to heat sources and fluids, volcanoplutonic arc rocks may show metasomatic and textural effects of several thermal events following igneous crystallization: submarine metamorphism, regional metamorphism, and contact metamorphism. Documentation of this recrystallization and attendant metasomatism from the North Fork-Salmon River arc in the Sawyers Bar area was provided by Hacker et al. [1992]. Evidence for submarine alteration comes primarily from consideration of bulk-rock compositions and oxygen isotopes. Substantial, relatively low-temperature $\left(100^{\circ}-200^{\circ} \mathrm{C}\right)$ submarine fluid-rock interaction caused enrichment of $\delta^{18} \mathrm{O}$ to $\sim 1 \%$ from probable basaltic igneous values of $\sim 6 \%$. Bulk compositional shifts (e.g., depletions in $\mathrm{Al}_{2} \mathrm{O}_{3}, \mathrm{Na}_{2} \mathrm{O}$, and $\mathrm{K}_{2} \mathrm{O}$ in mafic volcanic rocks, and $\mathrm{K}_{2} \mathrm{O}+\mathrm{Rb}$ addition and $\mathrm{Sr}$ depletion in sedimentary rocks) may have occurred during submarine metamorphism as well [Hacker et al., 1992].

Regional metamorphic assemblages in the North ForkSalmon River arc span upper greenschist to prehnite-actinolite and pumpellyite-actinolite facies. Estimates of physical conditions during greenschist-facies metamorphism indicate moderate to low pressures ( $300 \mathrm{MPa})$ at temperatures of $200^{\circ}-450^{\circ} \mathrm{C}$ [Hacker et al., 1992]. The Eastem Hayfork unit is inferred to have experienced the same metamorphic event as the North Fork and Salmon River rocks. Regional metamorphic minerals in Eastern Hayfork volcanic rocks are dominantly albite + epidote + actinolite \pm pumpellyite, although prehnite and zeolite minerals occur locally (Table 4). Biotite is prevalent in sedimentary rocks in the northem Klamaths but occurs only sporadically in the southern Klamaths (Table 4). Goodge and Renne [1991] reported a Permian bulk-rock Ar/Ar age from the matrix of the Eastern Hayfork which they inferred was a neocrystallization age but cannot be representative of the unit as a whole, which contains Late Triassic fossils.

Later contact metamorphism at 200-290 $\pm 50 \mathrm{MPa}$ and at peak temperatures approaching $600^{\circ} \mathrm{C}$ around mid-Jurassic cross-cutting plutons produced 3-4-km wide aureoles typified by gradual, systematic increases in the pargasite content of amphiboles, muscovite content of $\mathrm{K}$-white micas, and anorthite content of plagioclases in the mafic volcanic rocks. Granitoid intrusion also increased $\delta^{18} \mathrm{O}$ metabasalt values by an additional $5 \%$ within $3-4 \mathrm{~km}$ of plutons, probably by exchange with intercalated metasedimentary rocks [Hacker et al., 1992].

Barton and Hanson [1989] employed thermal models to demonstrate that regional low-pressure metamorphism only occurs in areas with a large fraction of relatively evenly distributed intrusions - otherwise sufficient heat is not available at shallow depths. It is possible that regional metamorphism of the North Fork-Salmon River arc was caused by heat advected to shallow crustal levels by plutons such as those that caused the contact metamorphism. The regional and contact metamorphism may thus be genetically linked and nearly coeval. Heat for both metamorphic events may have come from the volcanoplutonic edifice represented by the North Fork-Salmon River mafic magmatic arc or from the Wooley Creek calc-alkaline plutonic suite. The wide range of dike crystallization ages from 175 to $141 \mathrm{Ma}$ indicates that magmatism potentially capable of producing regional metamorphism spanned Middle Jurassic to Early Cretaceous time.

\section{TECTONIC HISTORY}

Although Davis et al. [1978] cautioned against fitting Klamath terranes into a coherent plate tectonic setting, shortly thereafter enough data had been collected to enable Burchfiel and Davis [1981] to suggest that the Eastern Hayfork unit formed in an accretionary wedge outboard of the Jura-Triassic volcanoplutonic arc in the eastern Klamaths. Wright [1981] 
TABLE 4. Regional Metamorphic Assemblages in Mafic Rocks

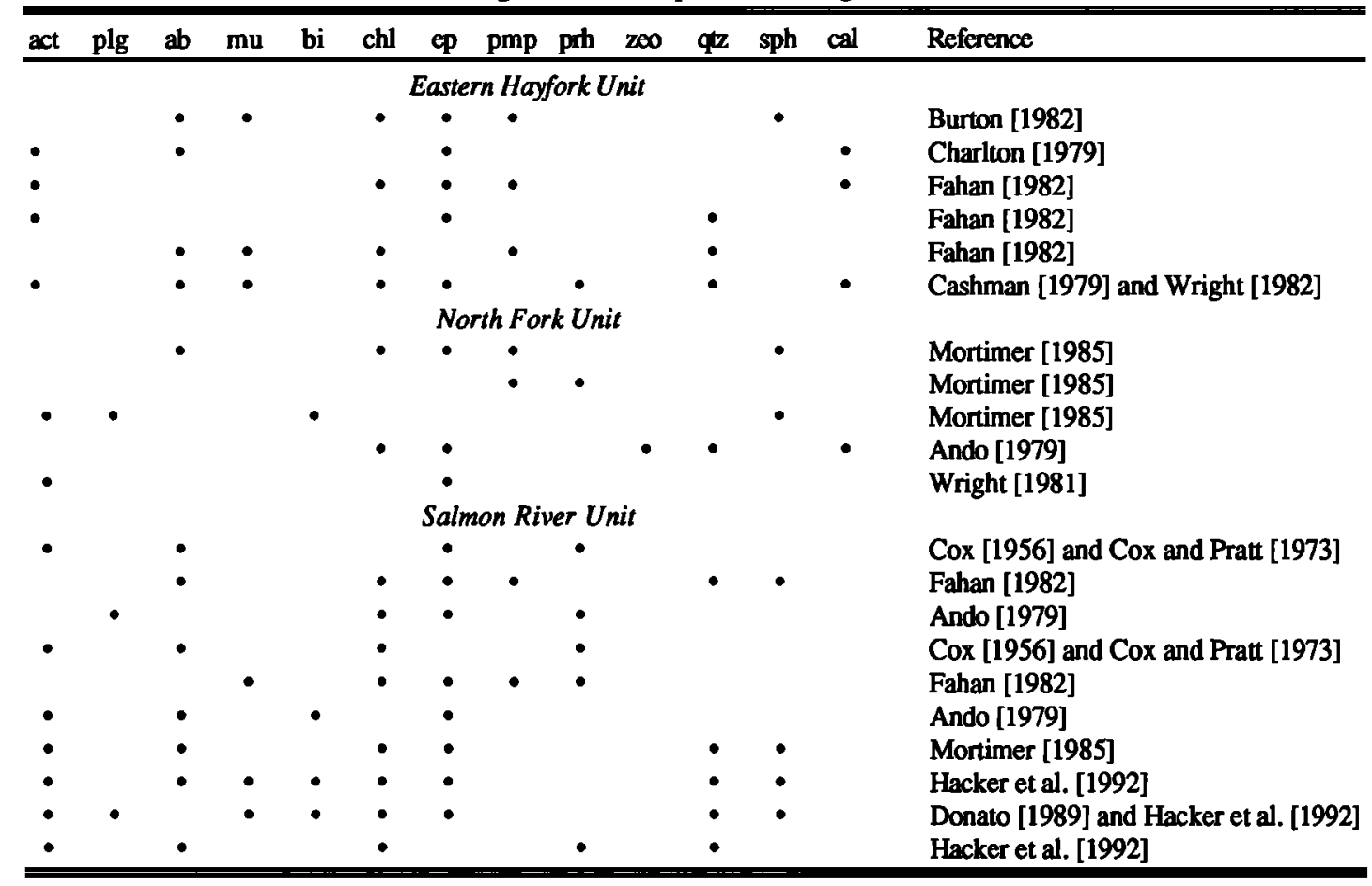

Mineral abbreviations, act; actinolite; plg, plagioclase; ab, albite; mu, muscovite; bi, biotite; chl, chlorite; ep, epidote; pmp, pumpellyite; prh, prehnite; zeo, zeolite; qtz, quartz; sph, sphene; cal, calcite.

added further the idea that the North Fork and St Claire Creek units might represent fore-arc mafic igneous crust and sediments between the arc and wedge. This tectonic setting has been modified slightly to include the Stuart Fork terrane as a somewhat older accretionary wedge [Goodge, 1990], but in general, this picture has undergone little further development.

Our interpretation, based on exposures in the central California Klamath Mountains is considerably different. We follow earlier views of the Eastern Hayfork unit as an accretionary wedge, but suggest that the North Fork and Salmon River units together represent an immature magmatic arc. The Salmon River unit is considered to be a tholeiitic volcanoplutonic complex, whereas the alkalic, mafic volcanic rocks are interpreted as related arc extrusives of somewhat atypical chemistry. The St Claire Creek unit represents pelagic sediments, and intercalated alkalic rocks suggest it was deposited near an intraoceanic arc.

North Fork-Salmon River volcanism was active at the same time as the eastern Klamath arc, and an immediate question is, What is the relationship between these two JuraTriassic magmatic arcs? Prior to Triassic time, radiolarians were deposited in the St Claire Creek chert and plagiogranite crystallized in the Salmon River unit (Figure 9). Highpressure metamorphism ended in now-exposed portions of the Stuart Fork terrane at $\sim 219 \mathrm{Ma}$, and at the same time, radiolarians were deposited in the Eastem Hayfork and $\mathbf{S t}$ Claire Creek units. At $200 \mathrm{Ma}$, gabbro crystallized in the Salmon River unit, coincident with radiolarian deposition in the Eastern Hayfork and St Claire Creek units. At 174-169 $\mathrm{Ma}$, the Western Hayfork arc formed, plutons of which intrude the Eastem Hayfork. A 175 Ma dike/sill intruded the Salmon
River unit and may be a part of Western Hayfork or North Fork-Salmon River magmatism. During the interval 170 $165 \mathrm{Ma}$ all these units were telescoped together, coincident with crystallization of 166-167 Ma old plutons and 166-170 Ma deformation in the eastem Klamaths [Renne and Scott. 1988]. Intrusion of arc tholeiitic dikes/sills was widespread until at least $141 \mathrm{Ma}$.

\section{CONCLUSIONS}

We completed a map delineating the rock units in the central Klamath Mountains of California. The map, which is based on the work of many geologists, permitted (1) the delineation of a north-south belt of rocks that crops out from one end of the Klamaths to the other [Irwin, 1972; Mortimer, 1984], and (2) the identification of key areas for petrological, structural, and geochronological investigation. Detailed studies in several of these key areas has resulted in a modified geologic interpretation of the central Klamath Mountains.

The Eastern Hayfork, North Fork, and Salmon River units, in conjunction with the St Claire Creek unit, make up the Sawyers Bar terrane [Emst, 1990]. The Eastem Hayfork is interpreted as an accretionary wedge developed beginning perhaps in Permian time, but nevertheless completed by the Middle Jurassic [Wright, 1982]. The North Fork and Salmon River units represent an immature volcanoplutonic arc that was active from Permian through at least Middle Jurassic time. The St Claire Creek unit apparently was deposited in a setting similar to the Eastern Hayfork but on the inboard (back-arc?) side of the North Fork-Salmon River arc. Volcanic rocks of the intraoceanic arc are interbedded with sedimentary rocks of 


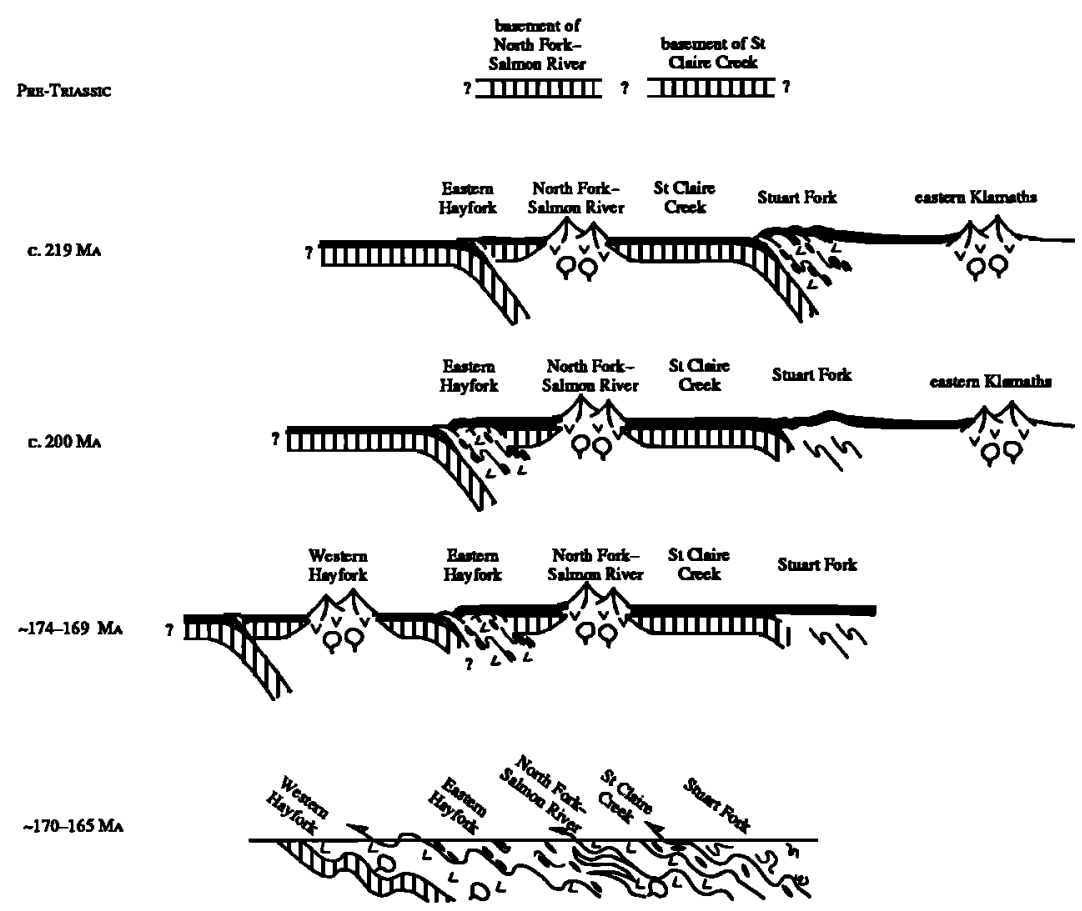

Fig. 9. Inferred diagrammatic tectonic history of the North Fork-Salmon River arc.

the outboard accretionary wedge, and hypabyssal rocks intrude the sedimentary as well as volcanic rocks. The westem edge of the terrane is defined by a Middle Jurassic fault that places the Middle Jurassic Western Hayfork calc-alkaline arc beneath the Sawyers Bar terrane [Wright, 1982]. The eastem edge of the Sawyers Bar terrane is a disrupted subduction zone thrust juxtaposing it against the Late Triassic Stuart Fork subduction complex [Hotz, 1977].

Late normal faulting and differential tilting have exposed different levels of the volcanoplutonic complex from ultramafic tectonite at the base, up through plutonic and hypabyssal rocks, and culminating in interbedded volcanic and sedimentary rocks. Deeper levels of the arc dominated by tholeiitic plutonic and hypabyssal rocks of the Salmon River unit are interlayered with and overlain by mafic, alkalic volcanic and volcanogenic rocks of the North Fork unit. A prolonged but low-rank heating history left the arc with a mixture of submarine and regional metamorphic effects of the low-pressure, moderate-temperature variety, overprinted locally by contact metamorphism.

Tholeiitic plutons and dikes/sills that range in age from 201 to $141 \mathrm{Ma}$ intrude the entire terrane, indicating that arc volcanism continued until the Cretaceous. Moreover, weak metamorphism of the hypabyssal rocks suggests that significant heat was retained regionally into Early Cretaceous time.

The terrane concept was born in the Klamath Mountains and led to the naming of at least 12 terranes - all fault bounded by definition. The value of the concept lies in the recognition that adjacent rock units need not have originated next to one another, and this has prompted a reexamination of whether the contacts between terranes are really faults. This study expands the work of earlier geologists to show that three "terranes," the Eastern Hayfork, North Fork, and Salmon River, are not separated from one another primarily by faults, but are linked by primary depositional and magmatic ties. These three units, along with the newly designated St Claire Creek unit, constitute the Sawyers Bar terrane, which is bounded by faults.

Many unanswered questions remain, but there is at least one especially important unresolved aspect of each unit. The Eastern Hayfork is homogeneous on a large scale, yet remarkably varied at smaller scales. The delineation of mappable subdivisions within the Eastern Hayfork would be a notable improvement and might help resolve whether formation of the accretionary wedge was a lengthy or shortlived event. Crystallization ages of the North Fork and Salmon River units remain poorly constrained. Whether the Salmon River unit is a Jurassic arc built upon older oceanic basement or an arc that was active from Permian to Jurassic time may be resolved through more detailed geochronology. Although the Eastern Hayfork sedimentary rocks appear to be interbedded with North Fork-Salmon River volcanic rocks on the basis of field mapping, radiolarian ages in the Eastem Hayfork predate most radiometric ages of the North ForkSalmon River immature arc. This is clearly an issue that requires resolution. Our interpretation of the North Fork unit as part of an immature arc hangs on two factors: the interfingering relationship with Salmon River rocks, the transitional VAB-WPA pyroxene chemistry, and whole-rock chemistry. Refutation or confirmation of this and other ideas advanced in this paper awaits future study.

Acknowledgments. Our synthesis relies heavily upon the earlier work of other geologists. Thanks to Nick Mortimer for permission to include unpublished trace-element data. We have benefited from discussions with Cal Barnes, Bob Coleman, Mary Donato, and from reviews by W. P. Irwin, M. M. Miller, D. Miller, J. L. Mosenfelder and J. E. Wright. This work was supported by Department of Energy grants DEFGO3-90ER14154 and 8802-121. 


\section{REFERENCES}

Allen, C.M., Intrusive relations and petrography of the Slinkard pluton, central Klamath Mountains, Califormia, M.S. thesis, 120 pp., University of Oregon, Eugene, 1981.

Ando, C.J., Structural and petrologic analysis of the North Fork terrane central Klamath Mountains, Califomia, Ph.D. dissertation, 197 pp., Univ. of Southem Calif., Los Angeles, 1979.

Ando, C.J., P. Cashman, and G. Davis, Geologic summary and road log of portions of the central Klamath Mountains, Califomia, in Guidebook to the Geology of the Klamath Mountains, northern California, edited by N. LindsleyGriffin and J.C. Kramer, Geol. Soc. Am. Cordilleran Section Meeting Guidebook, 1977.

Ando, C.J., W.P. Irwin, D.L. Jones, and J.B. Saleeby, The ophiolitic North Fork terrane in the Salmon River region, central Klamath Mountains, Califomia, Ged. Soc. Am. Bull., 94, 236-252, 1983

Barnes, C.G., J.M. Rice, and R.F. Gribble, Tilted plutons in the Klamath Mountains of Califomia and Oregon. J. Geophys. Res., 91, 6059-6071, 1986.

Barrows, A.G., Geology of the Hamburg-McGuffy Creek area, Siskiyou County, Califomia, and petrology of the Ton Martin ultramafic complex, Ph.D. dissertation, 301 pp., University of Califomia, Los Angeles, 1969.

Barton, M.D., and R.B. Hanson, Magmatism and the development of low-pressure metamorphic belts: Implications from the western United States and thermal modeling. Geol. Soc. An. Bull., 101, 1051-1065, 1989.

Blake, M.C., Jr., D.G. Howell, and D.L. Jones, Preliminary tectonostratigraphic terrane map of Califomia, U.S. Ged. Surv. Open File Rep. 82593, 1982

Blakely, R.J., R.C. Jachens, R.W. Simpson, and R.W. Couch, Tectonic setting of the southem Cascade Range as interpreted from its magnetic and gravity fields, Geol. Soc. Am. Bull., 96, 43-48, 1985

Blome, C.D., and W.P. Irwin, Tectonic significance of Late Paleozoic to Jurassic radiolarians from the North Fork terrane. Klamath Mountains, Califomia, in Pre-Jwassic rocks in western North American suspect terranes, pp. 77-89, edited by C.H. Stevens, Soc. Econ. Paleontol. Mineral., Los Angales, 1983.

Boms, DJ., Blueschist metarnorphism of the Yreka-Fort Jones area, Klamath Mountains, northem Califomia, Ph.D. dissertation, 167 pp., Univ. of Wash., Seattle, 1980.

Boms, D.J., Eclogites in the Stuan Fork terrane, Klamath Mountains, Califomia, Geol. Soc. Am. Abstr. Programs, 16, 271, 1984.

Brouxel, M., H. Lapierre, and J.-L. Zimmerman, Upper Jurassic mafic magmaric rocks of the eastern Klamath Mountains, northern Califomis, Geology, 17, 273-276, 1989.

Burchfiel, B.C. and G.A. Davis, Triassic and Jurassic tectonic evolution of the Klamath MtsSierra Nevada geologic terrane, The Geotectonic Development of California, Rubey Ser. I, edited by W.G. Emst, 50-70, 1981.

Burton, W.C., Geology of the Scoul Bar Mountains, northern Californis, M.S. thesis, 120 pp., Univ. of Orgon, Eugene, 1982.

Cashman, P.H., Geology of the Forks of Salmon area, Klamath Mountains, Califomia, Ph.D. dissertation, 212 pp., Univ. of Southem Calif., Los Angeles, 1979.

Charlton, D.W., Geology of part of the Ironside Mountain quadrangle, northem Califomia Klamath Mountains, Ph.D. dissertation, 542 pp., Univ. of Calif., Santa Barbara, 1979.

Coleman, R.G., M.D. Helper, and M.M. Donato Geologic map of the Condrey Mountains Roadless Area, Siskiyou County, Califomia,
U.S. Geol. Surv. Misc. Field Invest., MF. 1540A, scale 1:50,000, 1983.

Coleman, R.G. C.E Manning, M.M. Donato, N. Mortimer, and L.B. Hill, Tectonic and regional metamorphic framework of the Klamath Mountains and adjacent Coast Ranges, Califomia and Oregon, in Metamorphisn and Crustal Evolution of the Western United States, Rubey VII, Emst, W.G., 1061-1097, 1988.

Cox, D.P., Geology of the Helena Quadrangle, Trinity County, California, Ph.D. dissertation, 123 pp., Stanford Univ. Stanford, Calif., 1956.

Cox, D.P., and W.P. Prat, Submarine chert-argillite slide-breccia of Paleozoic age in the southem Klamath Mountains, California, Geol. Soc. Am. Bull., 84, 1423-1438, 1973.

Davis, G.A., Westward thrust faulting in the southcentral Klamath Mountains, Califomia, Geol. Soc. Am. Bull., 79, 911-934, 1968.

Davis, G.A. and P.W. Lipman, Revised structural sequence of pre-Cretaceous metamorphic rocks in the southem Klamath Mountains, Califomia, Geol. Soc. Am. Bull., 73, 1547$1552,1962$.

Davis, G.A., J.W.H. Monger, and B.C. Burchfiel, Mesozoic construction of the Cordilleran "collage", central British Columbia to central Califomia, in Mesozoic Paleogeography of the western United States, vol. 2, pp. 1-32, edited by D.G. Howell and K.A. McDougall, Soc. Econ. Paleontol. Mineral., Los Angeles, 1978.

Davis, G.A., C.J. Ando, P.H. Cashman, and L. Goullaud, Geologic cross section of the central Klamath Mountains, Califomia: Summary, Geol. Soc. Am. Bull., Part I, 91, 139-142, 1980.

Donalo, M.M., Metamorphism of an ophiolitic tectonic melange, Marble Mountains, northern Califomia Klamath Mountains, USA, $J$. Metamorph. Geol., 7, 515-528, 1989.

Donato, M.M., C.G. Bames, and W.P. Irwin, Northward continuation of the Hayfork terrane, north-central Klamath Mountains, Califomia, Geol. Soc. Am. Abstr. Programs, 13, $52,1981$.

Donaro, M.M., C.G. Bames, R.G. Coleman, W.G Ernst, and M.A. Kays, Geologic map of the Marble Mountain Wildemess Area, Siskiyou County, Califomia, U.S. Geol. Surv. Misc. Field Invest. MF-1452A, scale 1:48,000, 1982.

Donato, M.M., C.G. Bames, and G.G. Gary, Geologic map of the Orleans Mountain Roadless Area, Humboldt and Siskiyon Counties, Califomia, U.S. Geol. Swrv. Misc. Field Invest., MF-1526A, scale 1:62,500, 1983.

Emst, W.G., Chemically distinct mafic dike/sill sequences of contrasting age ranges, Sawyers Bar area, central Klamath Mountains, northem Califomia, J. Petrol., in press, 1992.

Emst, W.G., Mafic meta-igneous arc rocks of apparent komatiitic affinities, Sawyers Bar area, central Klamath Mountains, northern Califomia, Spec. Pub. Geochem. Soc., 1, 191. 208, 1987.

Emst, W.G., Accretionary terrane in the Sawyers Bar area of the western Triassic and Paleozoic belt, central Klamath Mountains, northem Califormia, in Paleozoic and early Mesozoic paleogeographic relations; Sierra Nevada, Klamath Mountains, and related terranes, edited by D.S. Harwood and M.M. Miller. Geol. Soc. Am. Spec. Pap. 255, 297-305, 1990.

Emst, W.G., B.R. Hacker, M.D. Banton, and G. Sen, Occurrence, geochemistry and igneous petrogenesis of magnesian metavolcanic rocks from the WTrPz belt, central Klamath Mountains, northem Califomia, Geol. Soc. Am. Bull., 103, 56-72, 1991.

Fahan, M.R., Geology and geochronology of part of the Hayfork terrane, Klamath Mountains. northem Califomia, M.S. thesis, 127 pp., Univ. of Calif., Berkeley, 1982.

Floyd, P.A., R. Shail, B.E. Leveridge, and W.
Franke, Geochemistry and provenance of Rhenohercynian synorogenic sandstones: Implications for tectonic environment discrimination, in Developments in Sedimentary Provenance Studies, edited by A.C. Morton, S.P. Todd, and P.D.W. Haughton, Geol. Soc. London Spec. Publ., 57, 173-188, 1991.

Fuis, G.S., JJ. Zucca, W.D. Mooney, and B Milkereit, A geologic interpretation of seismicrefraction results in northeastem Califomia, Geol. Soc. An. Bull., 98, 53-56, 1987.

Goodge, J.W., Polyphase metamorphic evolution of the Stuart Fork Terrane; a Late Triassic subduction complex in the Klamath Mountains, Northem Califomia, Ph.D. dissertation, 270 pp., University of Califomia, Los Angeles, 1987.

Goodge, J.W., Evolving early Mesozoic convergent margin deformation, central Klamath Mountains, northem Califomia. Tectonics, 8, 845-864, 1989 a.

Goodge, J.W., Polyphase metamorphic evolution of a Late Triassic subduction complex, Klamath Mountsins, northem Califomia, Am. J. Sci., $289,874-943,1989 b$.

Goodge, J.W., Tectonic evolution of a coherent Late Triassic subduction complex, Stuart Fork terrane, Klamath Mountains, northem California, Geol. Soc. Am. Bull. 102, 86-101, 1990.

Goodge, J.W., and P.R. Renne, Mid-Paleozoic petrotectonic signature of accretionary belts in the southem Klamath Mountains, Califomia, Geol. Soc. Am. Absir. Programs, 23, A480 A481, 1991.

Gray, G.G., Native terranes of the Central Klamath Mountains, Tectonics, 5, 1043-1054, 1986.

Gray, G.G., Structural, geochronologic, and depositional history of the westem Klamath Mountains, Califomia and Oregon: Implications for the early to middle Mesozoic tectonic evolution of the westem North American Cordillera, Ph.D. dissertation, 161 Pp., University of Texas, Austin, 1985.

Grover, T.W., Progressive metamorphism west of the Condrey Mountain dome, north-central Klamath Mountains, northem Califomia, M.S. thesis, 129 pp., University of Oregon, Eugene, 1984.

Hacker, B.R., Evolution of the northem Sierr Nevada metamorphic belt: petrological, structural, and Ar/Ar constraints, Geol. Soc. Am. Bull., in press, 1993.

Hacker, B.R., and J.W. Goodge, Comparison of Early Mesozoic high-pressure rocks in the Klamath Mountains and Sierra Nevada, in Paleozoic and early Mesozoic paleogeographic relations: Sierrs Nevada, Klamath Mountains, and related terranes, edited by D.S. Harwood and M.M. Miller, Geol. Soc. Am. Spec. Pap. 255, 277-296, 1990.

Hacker, B.R., W.G. Emst, and M.D. Baron, Metamorphism, geochemistry, and origin of magnesian volcanic rocks, Klamath Mountains, Califomia, J. Metamorph. Geol., 10, 55-69, 1992.

Hanks, C.L., The emplacement history of the Tom Martin ultramafic complex and associated metamorphic rocks north central Klamath Mountains, Califomia, M.S. thesis, 112 pp. University of Washington, Seattle, 1981.

Harper, G.D., J.B. Saleeby, and M. Heizler, Formation and emplacement of the Josephine ophiolite and orogeny in the Klamath Mountains, Califomia/Oregon: U/Pb zircon and $40 \mathrm{Ar} /{ }^{39} \mathrm{Ar}$ geochronology, J. Geophys. Res., in press, 1993.

Harper, G.D., and J.E. Wright, Middle to Late Jurassic tectonic evolution of the Klamath Mountains, California-Oregon, Tectonics, 3, 759-772, 1984. 
Helper, M.A., N.W. Walker, and F.W. McDowell Early Cretaceous metamorphic ages and middle Jurassic U-Pb zircon ages for the Condrey Mountain schist, Klamath Mountains, NW Califomia and SW Oregon, Geol. Soc. Am. Abstr. Programs, 21, 92, 1989.

Hill, L.B., A tectonic and metamorphic history of the north-central Klamath Mountains, California, Ph.D. dissertation, 248 pp., Stanford University, Stanford, Califomia, 1984.

Hotz, P.E., Geologic map of the Condrey Mountain quadrangle, and parts of the Seiad Valley and Hombrook quadrangles, Califomia, U.S. Geol Surv. Geol. Quad. Map, GQ-618, scale: $1: 62,500,1967$.

Hotz, P.E., Geology of the Yreka quadrangle, Siskiyou County, Califomia. U.S. Geol.Surv. Bull. 1436, 72 pp., 1977.

Hotz, P.E., Geologic map of the Yreka quadrangle and pans of the For Jones, Euna, and China Mountain quadrangles, Califomia, U.S. Geol. Surv. Open File Rep., OFR 78-12, scale: 1:62,500, 1978

Hotz, P.E., M.A. Lanphere, and D.A. Swanson, Triassic blueschist from northem Califomia and norh -central Oregon, Geology, 5, 659. 663, 1977.

Howell, D.G., and D.L Jones, Tectonostratigraphic terrane analysis and some terrane vernacular, in Proceedings of the Circum-Pacific terrane conference, ediled by D.G. Howell et al., Stanford Univ. Press, pp. 69, Stanford, Calif., 1984

Irwin, W.P., Preliminary geologic map of the Weaverville Quadrangle, Califomia, $U . S$. Geol. Surv. Misc. Field Invest., MF-275, scale 1:62,500, 1963

Irwin, W.P., Geology of the Klamath Mountains province, Calif. Div. Mines Geol. Bull., 190. 17-36, 1966.

Irwin, W.P., Terranes of the westem Paleozoic and Triassic belt in the southern Klamath Mountains, Califomia, U.S. Geol. Surv. Prof Pap. 800C, C101-C111, 1972.

Irwin. W.P., Reconnaissance geologic map of the Hayfork Quadrangle, Trinity County, Califomia, U.S. Geol. Surv. Misc. Field Invest Map MF-576, 1974

Inwin, W.P., Review of Paleozoic rocks of the Klamath province, in Peleozoic Paleogeography of the western Uniled States, edited by J.H. Stewart, C.H. Stevens, and A.E. Fritsche, Pacific Coast Paleogeography Symposium, vol. 1, p. 441-454, Soc. Econ Paleontol. Mineral., Los Angeles, 1977.

Irwin, W.P., Reconnaissance geologic map of the Hyampom Quadrangle, Trinity County. Califomia, US. Geol. Swrv. Misc. Field Invest. $M F-1809$, scale 1:62,500, 1985.

Irwin, W.P., Terranes of the Klamath Mountains, California and Oregon, in Sedimentation and Tectonics of western North America, 28th Intemational Geological Congress Field Trip Guide, vol. 2, p. 19-32, Am. Geophys. Union, Washington DC, 1989.

Irwin, W.P., D.L Jones, and E.A. Pessagno, Jr., Significance of Mesozoic radiolarians from the pre-Nevadan rocks of the southem Klamath Mountains, Califomia, Geology, 5, 557-562, 1977.

Irwin, W.P., D.L. Jones, and C.D. Blome, Map showing radiolarian localities in the westem Paleozoic and Triassic belt, Klamath Mountains, Califomia, US. Geol. Surv. Misc. Field Invest. Map MF́-1399, 1982.

Irwin, W.P., B.R. Wardlaw, and T.A. Kaplan, Conodonts of the westem Paleozoic and Triassic belt, Klamath Mountains, Califomia and Oregon, J. Paleontol., 57, 1030-1039, 1983.

Irwin, W.P., J.D. Yule, B.L Coun, A.W. Snoke, L.A. Stem, and W.B. Copeland, Reconnaissance geologic map of the Dubakella Mountain Quadrangle, Trinity, Shasta, and Tehama Counties, Califomia, U.S. Geol. Surv. Misc. Field Invest. Map MF-1808, 1985.

Jones, D.L. Synopsis of late Paleozoic and Mesozoic terrane accretion within the Cordillera of westem North America, in
Allochthonous Terranes, edited by J.F. Dewey et al., pp. 23-30, Cambridge University Press. New York, 1991.

Klein, C.W., Structure and petrology of a southeastem portion of the Happy Camp Quadrangle, Siskiyou County, northwest Califomia, Ph.D. dissertation, 288 pp., Harvard University, Cambridge, Massachuseus, 1975.

Lanphere, M.A., W.P. Irwin, and P.E. Hotz, Isotopic age of the Nevadan orogeny and older plutonic and metamorphic events in the Klamath Mountains, Califomia, Geol. Soc. Am. Bull., 79, 1027-1052, 1968.

Leeman, W.P., D.R. Smith, W. Hildreth, Z. Palacz, and N. Rogers, Compositional diversity of Late Cenozoic basalts in a transect across the southem Washington Cascades: implications for subduction zone magmatism, $J$. Geophys. Res., 95, 19,561-19,582, 1990

Mack, S., Geology and ground-water features of Scott Valley Siskiyou County, Califomia, U. S. Geol. Surv. Water Supply Paper, 1462,98 pp. 1958.

Masson, P.H., Geology of the Gunsight Peak district, Siskiyou County, Califomia, M.A thesis, 75 pp., Univ. of Calif., Berkeley, 1949.

Medaris, L.G., Geology of the Seiad Valley area, Siskiyou Couny, California, and petrology of the Seiad ultramafic body, Ph.D. dissertation, 333 pp., University of California, Los Angeles, 1966.

Miller, M.M., and J.B. Saleeby, Permian and Triassic paleogeography of the Eastem Klamath arc and Eastem Hayfork subduction complex, Klamath Mountains, Califomia, in Paleozoic Paleogeography of the Western United Siates-II, edited by J.D. Cooper and C.H. Stevens, Pacific Coast Paleogeography Symposium, vol. 67, p. 643-652, Soc. Econ. Paleontol. Mineral. Los Angeles, 1991.

Miller, M.M., and J.E. Wright, Paleogeographic implications of Permian Tethyan corals from the Klamath Mountains, California, Geology, $15,266-269,1987$

Mortimer, N., Petrology and structure of Pemian to Jurassic rocks near Yreka, Klamath Mountains, Califomia, Ph.D. dissertation, 83 pp., Stanford Univ., Stanford, Calif., 1984.

Mortimer, N., Structural and metamorphic aspects of Middle Jurassic terrane juxtaposition, northeastem Klamath Mountains, Califomia, in Tectonostratigraphic terranes of the CircumPacific Region, Earth Science Series, 1, pp. 201-214, edited by D.G. Howell, CircumPacific Council for Energy and Mineral Resources, Houston, Texas, 1985.

Nilsen, T.H., G.M. Barats, M.A. Elliott, and D.L. Jones. Geologic map of the outcrop of the Hombrook Formation, Oregon and Califomia U.S. Geol. Surv. Open File Rep., OFR 83-373, 1983.

Nisbet, E.G., and J.A. Pearce, Clinopyroxene composition in mafic lavas from differen tectonic settings, Contrib. Mineral. Petrol., 63 149-160, 1977 .

Ormerud, D.S. C.J. Hawkesworth, N.W. Rogers, W. P. Leemen, M.A. Menzies, Tectonic and magmatic transitions in the westem Great Basin, USA, Nature, 333, 349-353, 1988.

Pearce, J.A., The role of sub-continental lithosphere in magma genesis at destructive plate margins, In Continental basalts and mantle xenoliths, edited by C.J. Hawkesworth and M.J. Nomy, Shiva, Nantwich, 230-249, 1983.

Petersen, S.W., Geology and petrology around Titus Ridge, north-central Klamath Mountains, California, M.S. thesis, 73 pp., University of Oregon, Eugene, 1982

Pran, W.P., Geology of the Marble Mountain area, Siskiyou County, Califomia, Ph.D. dissertation, 116 pp., Stanford University, Stanford, Califomia, 1964.

Rawson, S.A., and S.W. Petersen, Structural and lithologic equivalence of the Rattlesnake Creek terrane and high-grade rocks of the western Paleozoic and Triassic belt, north-central Klamath Mountains, California, Geol. Soc. Am Abstr. Programs, 14, 226, 1982.
Renne, P.R., and G.R. Scott, Structural chronology, oroclinal deformation, and tectonic evolution of the southeastem Klamath Mountains, Califomia, Tectonics, 7, 1223-1242, 1988.

Roddick, J.C., The application of isochron diagrams in ${ }^{40} \mathrm{Ar}-{ }^{39}$ Ar dating: A discussion. Earth Planet. Sci. Lett., 41, 233-244, 1978.

Saleeby, J.B., Geochronological and tectonostratigraphic framework of SierranKlamath ophiolitic assemblages, in Paleozoic and early Mesozoic paleogeographic relations; Sierra Nevada, Klamath Mountains, and related terranes, edited by D.S. Harwood and M.M. Miller, Geol Soc. Am. Spec. Pap. 255. 93-114, 1990.

Saleeby, J.B., G.D. Harper, A.W. Snoke, and W.D. Sharp. Time relations and structuralstratigraphic pattems in ophiolite accretion, west central Klamath Mountains, Califomia, $J$ Geophys. Res., 87, 3831-3848, 1982.

Seyfert, C.K., Geology of the Sawyers Bar area, Klamath Mountains, northem Califomia, Ph.D. dissertation, 186 Pp., Stanford University, Stanford, Califomia, 1965.

Stevens, C.H., M.M. Miller, and M.K. Nestell, A new Permian Waagenophyllid coral from the Klamath Mountains, Califomia, J. Paleontol., 61, 690-699, 1987.

Stevens, C.H., M.D. Luken, and M.K. Nestell, The Upper Permian fusulinids Reichelina and Parareichelina in northem California: Evidence for long-distance tectonic transport, in Paleozoic Paleogeography of the Western United States-II, edited by J.D. Cooper and C.H. Stevens, Pacific Coast Paleogeography Symposium, vol. 67, p. 635-642, Soc. Econ. Paleontol. Mineral., Los Angeles, 1991.

Slorey, M., G. Rogers, A.D. Saunders, and D.J. Terrell, San Quintín volcanic field, Baja California, Mexico: 'Within-plate' magmatism following ridge subduction, Terra Nova, 1, 195202, 1989.

Taylor, S.R., and S.M. McLennan, The Continental Crust; Iss Composition and Evolution, Blackwell Scientific, Boston, Mass., 1985.

Trexler, D.T., Geology of the northwest quarter of the Cecilville quadrangle, Siskiyou County, Califomia, M.S. thesis, 133 pp., Univ. of Southem Calif., Los Angeles, 1968.

Welsh, J.L., Structure, petrology, and metamorphism of the Marble Mountains area, Siskiyou County, Califomia, Ph.D. dissertation, 250 pp., University of Wisconsin, Madison, 1982.

Wright, J.E., Geology and U-Pb geochronology of the westem Paleozoic and Triassic subprovince, Klamath Mountains, northem California, Ph.D. dissertation, 300 pp., Univ. of Calif., Santa Barbara, 1981.

Wright, J.E., Permian-Triassic accretionary subduction complex, southwestem Klamath Mountains, northem Califomia, J. Geophys. Res., 87, 3805-3818, 1982

Wright, J.E., and M.R. Fahan, An expanded view of Jurassic orogenesis in the western U.S. Cordillera: Middle Jurassic (pre-Nevadan) regional metamorphism and thrust faulting within an active arc environment, Geol. Soc. Am. Bull., 100, 859-876, 1988.

Wood, D. A., J. Tamey, J. Varet, J.-L. Joron, P. Fryer, and M. Treuil, Geochemistry of igneous rocks recovered from a transect across the Marianas trough, arc, fore-arc, and trench, sites 453 through 461 Deep Sea Drilling Project Leg 60, Initial Rep. Deep Sea Drilling Project, $60,611-645,1981$.

Zuces, JJ., G.S. Fuis, B. Milkereit, W.D. Mooney, and R.D. Catchings, Crustal structure of northeastem Califomia, J. Geophys, Res., 91 , 7359-7382, 1986

W.G. Emst, B.R. Hacker, and M.O.

McWilliams, Department of Geology, School of

Earth Sciences, Stanford University, Stanford, CA 94305-2115.

(Received April 10, 1992;

revised September $8,1992$.

accepted September 21, 1992) 